\title{
Toisto ja korjauksen rajat
}

\author{
Salla Kurhila ja Niina Lilja
}

\section{Johdanto}

Puhekumppanin puhetta toistamalla on mahdollista toteuttaa monenlaisia vuorovaikutustoimintoja. Edeltävän vuoron toistolla voidaan esimerkiksi hämmästellä aikaisemmin sanottua (Wilkinson \& Kitzinger 2006), ottaa vastaan uutta informaatiota (Thompson, Fox \& Couper-Kuhlen 2015), osoittaa erimielisyyttä (Schegloff 2007) tai näyttää, että edeltävän vuoron vastaanottamisessa on ongelma, eli aloittaa korjaus (Schegloff, Jefferson \& Sacks 1977). Klassisessa korjausartikkelissaan Schegloff, Jefferson ja Sacks (mas. 368) antavat korjausaloitteena toimivasta toistosta seuraavan esimerkin:

A: He likes that waider over there

B: Waider?

A: Waitress, sorry

Esimerkissä puhuja B nostaa toistolla edeltävästä vuorosta esiin ongelmalliseksi tai virheelliseksi kokemansa sanan, jonka puhuja A korjaa seuraavassa vuorossa. Kaikki korjausaloitteena toimivat toistot eivät kuitenkaan liity virheiden esiin nostamiseen, vaan korjausaloitetoistoilla voidaan osoittaa esimerkiksi myös, että toistetun sanan ymmärtämisessä (Robinson 2013) tai kuulemisessa (Koshik 2005) on ongelma sekä ilmaista alkavaa erimielisyyttä tai vaikeuksia hyväksyä sitä, mitä toinen puhuja juuri sanoi (Benjamin 2013; Benjamin \& Walker 2013; Svennevig 2008).

Analysoimme tässä artikkelissa toistomuotoisia korjausaloitteita suomalaisissa arkikeskusteluissa. Tavoitteenamme on selvittää, millaisia puheen vastaanottamisen ongelmia edeltävän vuoron (osittaisella) toistolla pyritään ratkaisemaan eli milloin ja miksi puhuja valitsee toiston korjausaloitekeinoksi. Suomalaisessa keskusteluntutkimuksessa on aikaisemmin tutkittu vuorovaikutuksen korjausilmiöitä erityisesti erilaisissa epäsymmetrisissä vuorovaikutustilanteissa, esimerkiksi kakkoskielisissä keskusteluissa (Kurhila 2006; Lilja 2010) ja keskusteluissa, joissa on mukana afaattisia (Klippi 1996; Laakso 1997) tai huonokuuloisia henkilöitä (Pajo 2013). Näissä tilanteissa on paljon "korjauspotentiaalia" joko kielitaidon tai keskustelukumppaneiden muista kompetenssieroista johtuen: esimerkiksi kakkoskielisissä keskusteluissa kielenkäytön kysymykset aiheuttavat usein ymmärtämisen ongelmia, ja nimenomaan näiden osoittamiseen käytetään toistomuotoisia korjausaloitteita (Lilja 2014). Tähänastisessa tutkimuksessa ei 
kuitenkaan ole perusteellisesti analysoitu toistokorjausaloitteiden käyttöä kielellisiltä ja muilta kompetensseiltaan tasavertaisten osallistujien välisissä ei-institutionaalisissa keskustelutilanteissa (ks. kuit. Haakana, Kurhila, Lilja \& Savijärvi 2016). Tavoitteenamme on täyttää tätä perustutkimuksessa olevaa aukkoa.

Koska keskustelukumppanin puheen toistamisella voidaan tehdä monenlaisia vuorovaikutuksellisia tekoja, ei ole aina selvää, milloin edeltävän vuoron (osittainen) toisto toimii korjausaloitteena ja milloin taas ei. Aiemmassa tutkimuksessa onkin tehty erilaisia ratkaisuja sen suhteen, millaisia toistoja on pidetty korjausjäsennyksen piirin kuuluvina (ks. esim. Selting 1996; Wilkinson \& Kitzinger 2006). Tämä saattaa aiheuttaa käsitteellistä sekaannusta ja vaikeuttaa tutkimustulosten kumuloitumista, mistä syystä onkin peräänkuulutettu ilmiöiden rajoja koskevaa tutkimusta (Kendrick 2015: 166). Tässä artikkelissa pohdimme, mikä on korjausaloitteena toimivien toistojen suhde niiden lähi-ilmiöihin, ja pyrimme lisäämään ymmärrystä siitä, missä korjausilmiöiden rajat kulkevat.

\section{Korjausaloitteet keskustelunanalyysissa}

Korjausjäsennyksellä viitataan keskustelunanalyyttisessa tutkimuksessa niihin systemaattisesti järjestyneisiin tapoihin, joilla vuorovaikutukseen osallistuvat puuttuvat puhumisessa, kuulemisessa ja puheen ymmärtämisessä oleviin ongelmakohtiin. Korjaukset toteutuvat korjausjaksoissa ja jäsentyvät tietyn systematiikan mukaan. Korjausjakson ensimmäinen osa on ongelmavuoro eli se vuoro, jossa korjauksen kohde on. Ongelmavuoron ei välttämättä tarvitse sisältää virhettä, vaan se muuttuu ongelmavuoroksi vasta, kun toinen keskustelija nostaa minkä tahansa vuoron osan korjauksen kohteeksi. Ongelmavuoron jälkeen korjausjaksossa on korjauksen aloittava vuoro. Jos korjauksen aloittaa ongelmallisen lausuman vastaanottaja, puhutaan toisen aloittamista korjauksista. (Ks. esim. Schegloff, Jefferson \& Sacks 1977; Kitzinger 2013.)

Toiston lisäksi korjausjakson aloittamiseen on monia muitakin keinoja. Ongelmia edeltävän puheen vastaanottamisessa voidaan osoittaa esimerkiksi kysymyssanoilla ja kysymyssanojen ja toistojen yhdistelmillä (ks. esim. Sidnell 2006), tarjoamalla tulkintaehdotus edeltävästä vuorosta puhekumppanin hyväksyttäväksi tai korjattavaksi (Antaki 2012; Benjamin 2012) tai esittämällä niin sanottu avoin korjausaloite (Drew 1997; Haakana 2011; Enfield ym. 2013). Myös puheen vastaanottajan kehollinen toiminta voidaan joissakin tilanteissa tulkita korjausaloitteeksi (Seo \& Koshik 2010; Rasmussen 2013; Pajo \& Klippi 2013; Mortenssen 2016). Korjausaloitteita seuraa tyypillisesti korjausvuoro, jossa esiin nostettu ongelma pyritään ratkaisemaan. Korjausjäsennyksessä on siis kysymys keskusteluvuorovaikutusta jäsentävästä rakenteesta. Tämän lisäksi korjaus on kuitenkin myös toimintaa, joka viivyttää puheen päälinjan etenemistä sen aikaa, kun ongelmakohtaa korjataan (Hayashi, Raymond \& Sidnell 2013).

Tässä artikkelissa analysoimme, millaisia vuorovaikutuksen ongelmia nimenomaan toistomuotoisilla korjausaloitteilla pyritään ratkaisemaan. Toistokorjausaloitteita on analysoitu muutamissa aikaisemmissa tutkimuksissa. Laajimmin korjausaloitteita on kartoitettu Max Planck -instituutin tutkijoiden kymmenen kieltä käsittävässä vertai- 
levassa tutkimuksessa (Dingemanse \& Enfield 2015). Tässä typologiseen vertailtavuuteen pyrkivässä tutkimuksessa ei otettu toistoa lähtökohtaiseksi kategoriaksi, vaan tutkijat jaottelivat korjausaloitteet sen mukaan, millainen suhde niillä oli ongelmavuoroon ja minkälaisia sekventiaalisia implikaatioita ne projisoivat. Näillä kriteereillä yhdeksi aloitetyypiksi muotoutui "kohdennettu vahvistuksen hakeminen" (restricted offer type), josta mainitaan, että se toteutetaan tyypillisesti toistolla (mas. 106). Kohdennettuja vahvistuksen hakemisia löytyi kaikista tutkittavista kielistä.

Nimenomaan toistokorjausaloitteisiin keskittyvässä aiemmassa kirjallisuudessa on havaintoja toisaalta korjausaloitteiden muotoilusta ja toisaalta siitä, millaisiin vuorovaikutuksellisiin ongelmiin ne kytkeytyvät. Muotoilun osalta ensimmäinen eronteko liittyy siihen, mitä edeltävästä puheesta toistetaan. Toistaa voidaan joko koko ongelmavuoro (ks. Robinson \& Kevoe-Feldman 2010) tai ongelmavuoron osa (ks. Robinson 2013). Jos toisto kohdistuu osaan ongelmavuorosta, toistaa voidaan joko ongelmallinen elementti tai se osa ongelmavuorosta, joka edeltää tätä elementtiä. ${ }^{1}$

Toistojen analyysin yhteydessä tuodaan usein esiin ajatus siitä, että toistaminen sinänsä ei riitä osoittamaan, että puheen vastaanottamisessa on ongelma. Edeltävän vuoron osittainen toisto voidaan kuulla korjausaloitteeksi vain, jos toistoon yhdistyy esimerkiksi kysyvä sävelkulku tai kysyvyyttä ilmaisevia partikkeleita tai kysymyssanoja. (Ks. esim. Dingemanse, Blythe \& Dirksmeyer 2014: 25.) Toistojen sävelkulun osalta aiemmat tutkimukset ovat kohdistuneet lähinnä indoeurooppalaisiin kieliin. Erityisesti englannin kielestä toistuva havainto on se, että korjausaloitteena toimivat toistot tuotetaan nousevalla sävelkululla, kun taas esimerkiksi uutta tietoa vastaanottavien toistojen sävelkulku voi olla laskeva (ks. Schegloff 1997; Robinson 2013; Thompson, Fox \& Couper-Kuhlen 2015). Benjamin ja Walker (2013) ovat tutkineet sävelkulultaan korkealle nousevia ja sitten laskevia toistoja (high rise fall repeats), jotka liittyvät erityisesti hyväksyttävyyden ongelmiin: heidän analyysinsa mukaan tällaisen toiston tuottaja osoittaa, että hänellä on syystä tai toisesta vaikeuksia hyväksyä edeltävää vuoroa. Prosodian ja erityisesti sävelkulun on havaittu myös erottelevan korjausaloitteina toimivia toistoja esimerkiksi niistä toistoista, joiden pääasiallinen tehtävä on hämmästellä edellä sanottua. Hämmästelevien toistojen prosodiaa luonnehtivat lausuman sisäinen suuri vaihtelu sävelkorkeudessa sekä ympäristöä suurempi äänenvoimakkuus (Selting 1996). Sävelkulun lisäksi toistojen kysyvää funktiota saatetaan osoittaa toistoihin liittyvillä partikkeleilla (ks. esim. Wu 2006). Suomalaisten keskustelujen korjausaloitteisiin, erityisesti ymmärrysehdokkaisiin, liittyy usein vuoronalkuisia tai -loppuisia partikkeleita (ks. Haakana ym. 2016). Tämän tutkimuksen aineistona oleviin toistokorjausaloitteisiin partikkeleita ei kuitenkaan juuri yhdisty. ${ }^{2}$

1. Ongelmavuoron osittaisiin toistoihin on viitattu englanninkielisessä kirjallisuudessa esimerkiksi termeillä partial questioning repeat (esim. Robinson 2013: 261) ja trouble-presenting repeat (Dingemanse, Blythe \& Dirksmeyer 2014: 22) ja sellaisiin osittaisiin toistoihin, jotka toistavat ongelmallista elementtiä edeltävän osan ongelmavuorosta, termeillä hanging repeat (Rossi 2015: 274) ja incomplete repeat (Kendrick 2015: 173).

2. Niitä muutamaa tapausta, joissa edeltävän vuoron osittaisiin toistoihin liittyy aineistossamme partikkeli, yhdistää se, että korjausaloitteen ja ongelmavuoron välissä on muuta puhetta. Korjausta aloittava vuoro on siis etäällä ongelmavuorosta, ja partikkeli näyttää mahdollistavan tämän korjausta aloittavan vuoron myöhästymisen (ks. myös Haakana ym. 2016). 
Aiemmassa tutkimuksessa on tehty jonkin verran huomiota myös siitä, millaisiin ongelmiin toistomuotoisilla korjausaloitteilla reagoidaan. Esimerkiksi Robinson (2013) analysoi ongelmavuoron osittaisia toistoja, joiden käsittelyä ohjaa osallistujien suuntautuminen toistensa tietämykseen. Robinsonin mukaan toiston vastaanottaja käsittelee toistoa korjausaloitteena, jos hän päättelee, että toistaja ei tunne toistamansa sanan merkitystä. Jos vastaanottaja taas ajattelee toistajan tuntevan sanan, toisto tulkitaan merkiksi alkavasta erimielisyydestä. (Mts. 265.) Robinson ja Kevoe-Feldman (2010) ovat tarkastelleet koko edeltävän vuoron toistoja ja havainneet, että niiden avulla usein osoitetaan, että toistettu vuoro (tyypillisesti kysymys) liittyy jollakin tavalla ongelmalliseen vuorovaikutustoimintaan.

Kaikkiaan aiemmista toistokorjausaloitteita käsittelevistä tutkimuksista käy ilmi myös se, että korjausaloitteena toimivien toistojen erottaminen esimerkiksi uutta tietoa vastaanottavista toistoista ei ole yksinkertaista. Edeltävää puhetta vastaanottavia (responsiivisia) toimintoja analysoivassa tutkimuksessaan Thompson, Fox ja CouperKuhlen (2015: 86) toteavat osuvasti, että heidän tutkimansa sadat tapaukset osoittavat korjausaloitteen olevan jatkumoluonteinen toiminto. Onkin ehkä niin, että erilaisten korjausta aloittavien vuorojen välillä on aste-eroja siinä, miten selvästi ne aloittavat korjausta. Aina eri vuorovaikutustoimintoja ei voi täysin erottaa toisistaan, ja toisinaan sama vuoro saattaa toimittaa kahta samanaikaista toimintaa (ks. myös Levinson 2013). Tässä artikkelissa tavoitteenamme on tuoda lisäselvyyttä siihen, miten korjausilmiöiden rajoja voisi hahmottaa ja mikä erottaa korjausaloitteena toimivia toistoja niiden lähi-ilmiöistä.

\section{Aineisto ja kokoelman koostamisen kriteerit}

Aineistomme koostuu 37,5 tunnista suomenkielisiä ääni- ja videotallennettuja arkikeskusteluja. Osa aineistosta on peräisin Helsingin yliopiston keskusteluntutkimuksen arkistosta, ja osa on itse tallentamaamme. Kaikki keskustelutilanteet ovat vapaita ja epämuodollisia; puhujat ovat ystäviä, sukulaisia tai tuttavia keskenään, kaikki ovat aikuisia ja puhuvat ensikielenään suomea. ${ }^{3}$ Aineistossa on sekä puhelinkeskusteluja että kasvokkaisia vuorovaikutustilanteita. Kasvokkaisia vuorovaikutustilanteita analysoidessamme olemme kiinnittäneet huomiota myös toistokorjausaloitteisiin liittyvään keholliseen toimintaan. Aineisto on litteroitu keskustelunanalyyttisin menetelmin ja kehollisen toiminnan litteroinnissa on käytetty Mondadan (2016) kehittämiä konventioita (ks. litterointimerkit liitteenä).

Hankkeessa kävimme läpi kaikki aineistossa esiintyvät korjausaloitteet. Ne on esitetty taulukossa 1 sen mukaan, kuinka tarkkaan korjausaloite osoittaa ongelma-

3. Tutkimuksemme valmistui osana Helsingin yliopiston rahoittamaa hanketta Korjauskäytänteet ja ymmärryksen ylläpito vuorovaikutuksessa, jossa tavoitteena oli analysoida sitä, millaisin keinoin suomalaisissa arkikeskusteluissa ratkotaan puheen vastaanottamisessa olevia ongelmakohtia. Hankkeessa tarkastelun kohteena olivat arkikeskustelut, joiden osallistujat ovat keskenään kielellisiltä ja kognitiivisilta taidoiltaan mahdollisimman tasavertaisia. 
vuorosta ongelmakohdan. Toistokokoelmaamme kuuluu 46 tapausta, mikä tekee toistoista kysymyslauseiden ja ongelmien eksplikointien jälkeen aineistomme pienimmän korjausaloiteryhmän.

Taulukko 1.

Aineiston korjausaloitteet ( $N=522$ / 37,5 tuntia).

\begin{tabular}{lc} 
Korjausaloite & N \\
\hline Avoin & 156 \\
\hline Kysymyssana & 85 \\
\hline Kysymyssana + toisto & 68 \\
\hline Toisto & 46 \\
\hline Ymmärrysehdokas & 135 \\
\hline Kysymyslause & 29 \\
\hline Kuulemis-/ymmärrysongelman eksplikointi & 3 \\
\hline
\end{tabular}

Toistokorjausaloitteiden ryhmä on paitsi kooltaan pieni myös sisällöllisesti sekakoosteinen. Jo alustava katsaus aineistoomme näyttää, että toistot ovat myös korjausaloitteina hyvin monikäyttöinen vuorovaikutusresurssi.

Toistokokoelmaa koostaessamme olemme tehneet rajauksia, jotka ovat osin samoja ja osin erilaisia kuin aiemmassa tutkimuksessa tehdyt rajaukset. Olemme laskeneet toistoiksi vuorot, joissa edeltävä vuoro tai osa siitä tuotetaan uudelleen (lähes) identtisesti. Vaihtelua voi kuitenkin olla esimerkiksi persoonamerkinnässä, ja yleensä toistot ovat myös prosodialtaan erilaisia kuin alkuperäinen vuoro tai sen osa. Toistoina pidämme myös sellaisia tapauksia, jotka ovat kuultavissa tarkoituksellisiksi edeltävän vuoron toistoiksi, vaikka seuraavissa vuoroissa kävisikin ilmi, että toistaja on kuullut vuoron (osin) väärin (ks. esim. 2 s. 220-221).

Toistokokoelmamme ulkopuolelle olemme jättäneet tapaukset, joissa edeltävän vuoron sisältö muotoillaan uudelleen. Päädyimme lopulta jättämään kokoelmastamme pois myös sellaiset toistot, joissa ei ole muuta leksikaalista ainesta kuin verbi, johon liittyy ko-liitepartikkeli tai vai-partikkeli (onko, eikö, oot vai, sai vai jne.; vrt. esim. Sorjonen 1997: 130-131). Tämän rajauksen taustalla oli havaintomme siitä, että interrogatiiviset verbin toistot vaikuttavat varsin rituaalistuneelta tavalta ottaa vastaan uutta tietoa: ne eivät aineistossamme aina kirvoita aiemmalta puhujalta edes vahvistusta, eli niitä ei pidetä osoituksena kuulemisen tai ymmärtämisen ongelmallisuudesta eikä niillä ole selviä sekventiaalisia seuraamuksia (ks. esim. 1). Myös muuntyyppiset edeltävässä vuorossa esiin tuodun uuden tiedon vastaanotot olemme jättäneet kokoelman ulkopuolelle, jos niihin ei sisälly mitään vihjettä siitä, että toistajalla olisi vaikeuksia kuulla, ymmärtää tai hyväksyä edeltävää vuoroa. Vertailun kannalta on huomattava, että tällaisia $k o$-liitepartikkelin tai vuoronloppuisen vai-partikkelin sisältäviä verbin toistoja on aineistossamme melko paljon. Esimerkki 1 havainnollistaa tällaista kokoelmamme ulkopuolelle jäänyttä tapausta: 
(1) Kokoelmasta pois jätetty toisto

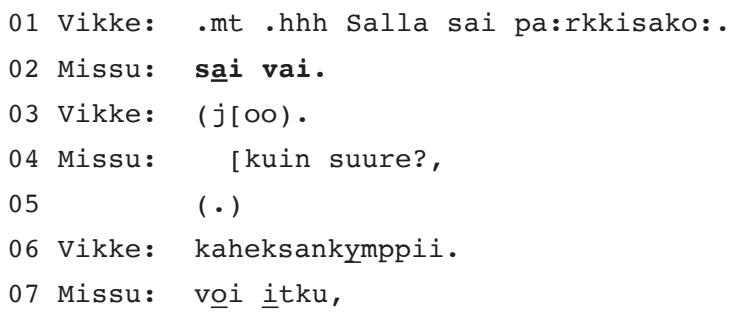

Tässä puhelinkeskustelussa Vikke kertoo ystävälleen Missulle uutisen kolmannesta henkilöstä (r. 1). Missu ottaa uutisen vastaan verbintoistolla, jota seuraa vaipartikkeli (r. 2). Vikke vahvistaa toiston seuraavassa vuorossa (r. 3), jolloin voidaan ajatella, että toisto luo keskusteluun välisekvenssin - odotuksen toiston hyväksymisestä tai hylkäämisestä. On kuitenkin huomattava, että Missulla ei vaikuta olevan tarvetta saada reaktiota toistoonsa, sillä hän jatkaa kysymällä yksityiskohtia uutisesta (r. 4) lähes samanaikaisesti kuin Vikke tuottaa vahvistuksensa. Koska Missun toisto ei osoita, että hänellä olisi vaikeuksia kuulla, ymmärtää tai hyväksyä edeltävää vuoroa, emme ole sisällyttäneet sitä (tai muita vastaavanlaisia tapauksia) toistokorjausaloitekokoelmaamme.

Rajanvedon hankaluus nimenomaan korjausaloitteena toimivien toistojen ja uutta tietoa vastaanottavien toistojen välillä on nostettu esiin myös aiemmassa tutkimuskirjallisuudessa (ks. esim. Thompson, Fox \& Couper-Kuhlen 2015: 60-64; Dingemanse \& Enfield 2015: 100; Kendrick 2015: 181). ${ }^{4}$ Toistokokoelmamme koostamisessa olennaista onkin ollut sen pohtiminen, millaiset toistot toimivat korjausaloitteina ja millaiset eivät. Tässä yhtenä tärkeänä kriteerinä on ollut toistoa seuraava vuoro: jos tämä vuoro käsittelee toistoa korjausaloitteena eli jos puhuja siinä esimerkiksi ryhtyy selittämään toistetun sanan merkitystä, olemme pitäneet toistoa korjausaloitteena. Aina toistoa seuraava vuoro ei kuitenkaan yksiselitteisesti osoita, käsitteleekö puhuja toistoa korjausaloitteena vai jonakin muuna toimintana. Näin on esimerkiksi tapauksissa, joissa toistoa seuraa jokin dialogipartikkeli (ks. ryhmiä 3-4, joita tarkastelemme luvuissa 4.3-4.4). Toistoa seuraava partikkeli on korjaustulkinnan kannalta monitulkintaisempi kuin toistetun ilmauksen selitys, mutta emme ole pitäneet partikkelia korjaustapauksia rajaavana kriteerinä, vaan toistokorjausaloitteita tunnistaessamme olemme analysoineet toiston koko sekventiaalista ympäristöä: niin sitä, millainen vuoro korjausvuoroa seuraa, kuin sitä, millainen toistoa edeltävä ongelmavuoro on toiminnaltaan ja millainen mahdollinen laajempi toiminta (esim. tarinankerronta) on käynnissä.

Myös prosodia on yhteydessä siihen, miten puheen vastaanottaja toistoa käsittelee. Olemme käyneet aineistomme toistojen prosodiaa läpi pääosin auditiivisesti ilman akustisia mittauksia ja analysoineet sitä osana korjausjakson paikallista kontekstia. Osa

4. Benjamin ja Walker (2013) nostavat esiin myös toiminnan ja rakenteen erottamisen tärkeyden toiston kohdalla: "it is crucial to regard repetition as a linguistic resource - as a component of a practice - rather than a practice in itself" (mas. 133). 
(vanhoista) nauhoituksista on äänenlaadultaan niin huonoja, että akustinen analyysi olisi hyvin tulkinnanvaraista. Joistakin kokoelmamme toistoista olemme kuitenkin saaneet analysoitua prosodisia piirteitä Praat-ohjelman avulla. Kun esittelemme seuraavaksi erityyppisiä toistotyyppejä, esitämme jokaisesta toistotyypistä yhden esimerkin havainnollistamalla tälle ryhmälle tyypillisiä prosodisia piirteitä kuvion avulla. Pääosin toistoista pystyy korvakuuloltakin suhteellisen helposti hahmottamaan, miltä ne kuulostavat, ja olemme olleet yksimielisiä tulkinnoissamme. ${ }^{5}$ Myös esimerkiksi Benjamin ja Walker (2013) toteavat toistokorjausaloitteiden prosodiaa käsittelevässä artikkelissaan, että heidän analysoimiensa toistojen intonaatiokuvio on kuultavissa ja mitattavissa (mas. 114). He myös korostavat tulkinnan ja analyysin ensisijaisuutta sävelkulkukuvion tunnistamisessa verrattuna absoluuttisiin frekvenssimittauksiin (mas. 114, alaviite 5).

\section{Aineiston toistokorjausaloitteet}

Seuraavaksi analysoimme aineistomme toistokorjausaloitteita tapausryhmä kerrallaan. Keskeinen kriteeri tapausten ryhmittelyssä on ollut se, millaiseen ongelmaan korjausaloite reagoi, sekä se, millaiseen sekventiaaliseen asemaan se sijoittuu. Prosodian osalta olemme pyrkineet tavoittamaan erityyppisille toistokorjausaloitteille ominaisia piirteitä.

Aloitamme analyysin käsittelemällä esimerkkejä, joissa toistokorjausaloite liittyy kuulemisongelmien käsittelyyn (luku 4.1). Toiseksi analysoimme tapauksia, joissa toistolla osoitetaan, että toistettua sanaa on selitettävä, jotta se olisi puheen vastaanottajalle kontekstissaan ymmärrettävä (luku 4.2). Nämä kaksi ensimmäistä ryhmää ovat hyvin samankaltaisia, sillä molemmissa toistokorjausaloitteella toistetaan edeltävästä vuorosta yksi sana ja toisto tuotetaan melko tasaisella sävelkululla. Ero kuulemisen ja ymmärtämisen ongelmien välille rakentuu vasta retrospektiivisesti sen kautta, miten toistoa käsitellään keskustelussa. Kolmas toistokorjausaloitteiden ryhmä koostuu tapauksista, joissa toisto edeltää korjausta tai erimielisyyden ilmausta (luku 4.3). Neljänteen ryhmään kuuluvat toistot topikalisoivat odotuksenvastaista tietoa (luku 4.4). Kolmannen ja neljännen ryhmän toistot eroavat kahden ensimmäisen ryhmän toistoista prosodian osalta: ne ovat prosodisesti selvästi kohosteisempia. Erityisesti neljännen ryhmän tapausten analyysin yhteydessä nousee esiin kysymys siitä, mitä toimintoja voi laskea korjausilmiöiksi ja missä korjauksen rajat kulkevat.

\subsection{Toisto osoittaa kuulemisen ongelmia}

Yksi toistokorjausaloitteiden käyttöympäristö liittyy kuulemisongelmien osoittamiseen ja ratkaisemiseen. Aineistossamme toistoja käytetään kuulemisongelmien osoittami-

5. Omien tapaamistemme lisäksi olemme kuunnelleet ja käyneet läpi toistojen prosodiaa tutkimustapaamisissa Giovanni Rossin, Anna Vatasen, Auli Hakulisen ja Melisa Stevanovicin kanssa. Kiitos ryhmälle paneutuneesta analyysista ja tarkoista havainnoista. Erityiskiitos Giovanni Rossille, joka on tehnyt Praat-kuviot toistoistamme. Anna Vataselle kiitos myös käsikirjoituksemme kommentoinnista. 
seen kahdella eri tavalla. Ensiksikin aineistossamme on tapauksia, joissa puhuja toistaa osan edeltävästä vuorosta väärin. Tällaiset toistot osoittautuvat väärinkuulemisiksi jälkikäteen sen kautta, miten vuorovaikutuskumppanit niitä käsittelevät. Toinen tapa osoittaa toistolla kuulemisongelmaa on toistaa ongelmavuorosta ne osat, jotka ympäröivät huonosti kuultua elementtiä (ks. myös Rossi 2015: 274; Kendrick 2015: 173). Esitämme ensin väärinkuulemistapauksen (esim. 2) ja sen jälkeen tapauksen, jossa on kyse osittaisesta kuulemisesta (esim. 3).

Esimerkissä 2 on siis kysymys väärinkuulemisesta. Siinä Riitta, Maiju, Jaana ja Leena istuvat kahvipöydässä Riitan kotona. Esimerkin alussa Maiju osoittaa kädessään olevalla haarukalla ulos (r. 1). Muiden katse seuraa hänen osoittavaa elettään, ja Maiju esittää kysymyksen (r. 1).

(2) Väärinkuuleminen, olio

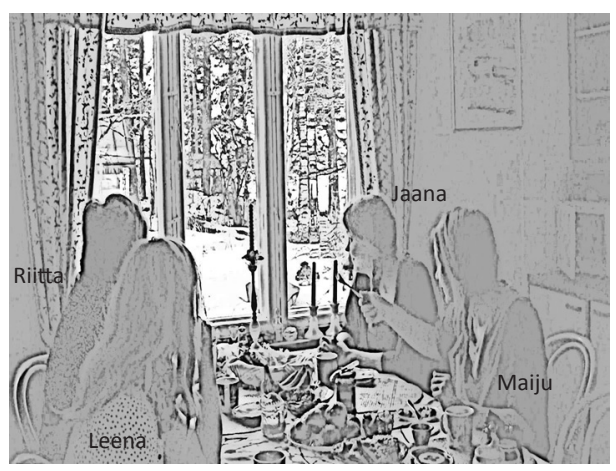

Kuva 1.

01 Maiju: mikä +>tuol on< tuolla *pihalla tụo (.) follio + +osoittaa oikeassa kädessä olevalla haarukalla ikkunasta ulos+ *muut katsovat haarukan osoittamaan suuntaan --> r6 *kuva 1

02 $+(0.1) \quad+(0.3)$ +Maiju laskee haarukan alas pöydälle+

$\rightarrow$ Ritta: ollio;

04 Maiju: tommone +[folio +

+osoittaa haarukalla ulos+

05 Jaana: [folio

06 Riitta: >ai foli ${ }^{\circ} 0^{\circ}<$ (.) no asen takia että ku --> katse Maijuun --> siinä om minun tuo hevos^kastanja ettei (.)

^Maiju katsoo ikkunasta ruokalautaseen --> nuo jänikset syö sitä 
09 Maiju: aiva

10 Riitta: mm (.) ku se käy kuulemma niitte hampaisii

Riitta toistaa sanan (r. 3), joka ei sellaisenaan esiinny sitä edeltävässä ongelmavuorossa. Sana olio on kuitenkin niin lähellä folio-sanaa, että on tarkoituksenmukaista ajatella, että Riitta pyrkii toistamaan ongelmavuoron viimeisen sanan. Prosodisilta ominaisuuksiltaan toistoa voi luonnehtia neutraaliksi, ja sävelkulultaan se on lievästi laskeva, kuten kuviosta 1 käy ilmi.

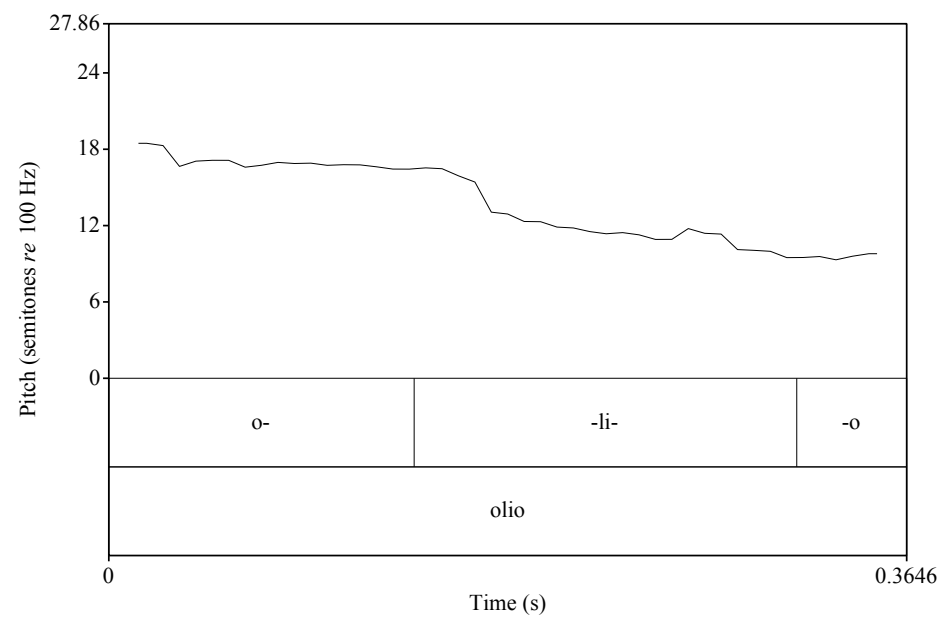

Kuvio 1.

olio-toiston sävelkulku.

Esimerkissä 2 toistoa seuraavat vuorot osoittavat, että keskustelukumppanit tulkitsevat Riitan toiston osoittavan, että Riitta on kuullut edeltävän vuoron viimeisen sanan väärin, sillä sekä Maiju että Jaana toistavat Riitan toiston jälkeen ongelmavuoron foliosanan. Riitan seuraava ai-partikkelilla alkava vuoro (r. 6) osoittaa, että kuultuaan nyt oikean sanan hän oivaltaa, mihin Maijun esittämä kysymys viittaa (ks. myös Koivisto 2015a), ja pystyy vastaamaan siihen.

Olennaista on ottaa huomioon, että Riitta ei itse välttämättä vielä toistoa lausuessaan ajattele kuulleensa väärin. Sen sijaan hän toistaa sanan, jonka ajattelee kuulleensa, ja hakee siihen selvennystä. Kaikkien osallistujien katse on suuntautunut Maijun kysymykseen liittyvän osoittavan eleen myötä ikkunasta ulos (kuva 1). Jos Riitta kuulee Maijun puhuvan oliosta, hän ei ehkä näe ikkunasta mitään sellaista, mikä vastaisi tätä. Näin ollen hän hakee sanalle selvennystä toistamalla sen. Tässä mielessä nämä väärinkuulemistapaukset ovat hyvin samankaltaisia kuin selitystä hakevat toistot (ks. esim. 4-5) - ero ryhmien välille syntyy vasta siinä, miten toistoja käsitellään niitä seuraavassa keskustelussa.

Svennevig (2008) on esittänyt, että korjausaloitteiden käsittelyä ohjaisi preferenssijäsennys, jonka mukaan kaikenlaisia ongelmia käsiteltäisiin ensisijaisesti kuulemisongelmina. Näin siksi, että kuulemisen ongelmia voi pitää yksinkertaisempina tai hel- 
pompina kuin ymmärrysongelmia, joiden voidaan helposti tulkita liittyvän puhujien puutteelliseen kompetenssiin. Aineistomme ei kuitenkaan suoraan tue tätä Svennevigin esittämää ajatusta eikä näitä edeltävän vuoron toistoja aina ensisijaisesti käsitellä kuulemisen ongelmina - vaikka esimerkissä 2 näin tehdäänkin. Pikemminkin ehdotamme analyysimme pohjalta, että toistomuotoisten korjausaloitteiden käsittelyä ei ohjaa ainakaan yksinomaisesti preferenssijäsennys, vaan toistojen käsittelyssä olennaisia ovat monet sekventiaaliset ja toimintakontekstiin liittyvät vihjeet. Esimerkissä 2 keskeistä on se, että kaikki vuorovaikutustilanteen osallistujat näkevät ikkunasta saman maiseman: näin ollen Maijun ja Jaanan on helppo päätellä Riitan toiston liittyvän kuulemisen ongelmaan.

Aiemmassa tutkimuksessa käsitellyistä kuulemisehdokkaista (ks. esim. Koshik 2005) tässä alaluvussa tarkasteltavat toistot eroavat sikäli, että toistettu sana toistetaan "väärin". Tämän vuoksi toistoa ei seuraavassa vuorossa tyydytä vain vahvistamaan vaan toistettu elementti korjataan vastaamaan sitä sanaa, joka ongelmavuorossa esiintyi.

Kuulemisongelmiin liittyvät myös toistot, joissa ongelmavuorosta toistetaan ne osat, jotka kuultiin. Tällaisia toistoja on aikaisemmassa kirjallisuudessa nimitetty "epätäydellisiksi toistoiksi" (incomplete repeat, Kendrick 2015: 173) ja "ilmaan jääviksi toistoiksi" (hanging repeat, Rossi 2015: 274). Esimerkki 3 havainnollistaa tällaista tapausta. Siinä Leena on kertomassa muille tarinaa siitä, miten eräässä maassa, jossa hänen tuttavansa on vieraillut, käytettiin merenrantaa vessana. Hänen kertomuksensa päättyy evaluaatioon (r. 7, 9). Kertomuksen päätöstä seuraavassa vuorossa (r. 11) Jaana toistaa Leenan edeltävästä vuorosta että-konjunktiolla alkavan osan osittain.

(3) Osittainen kuuleminen, rannalla

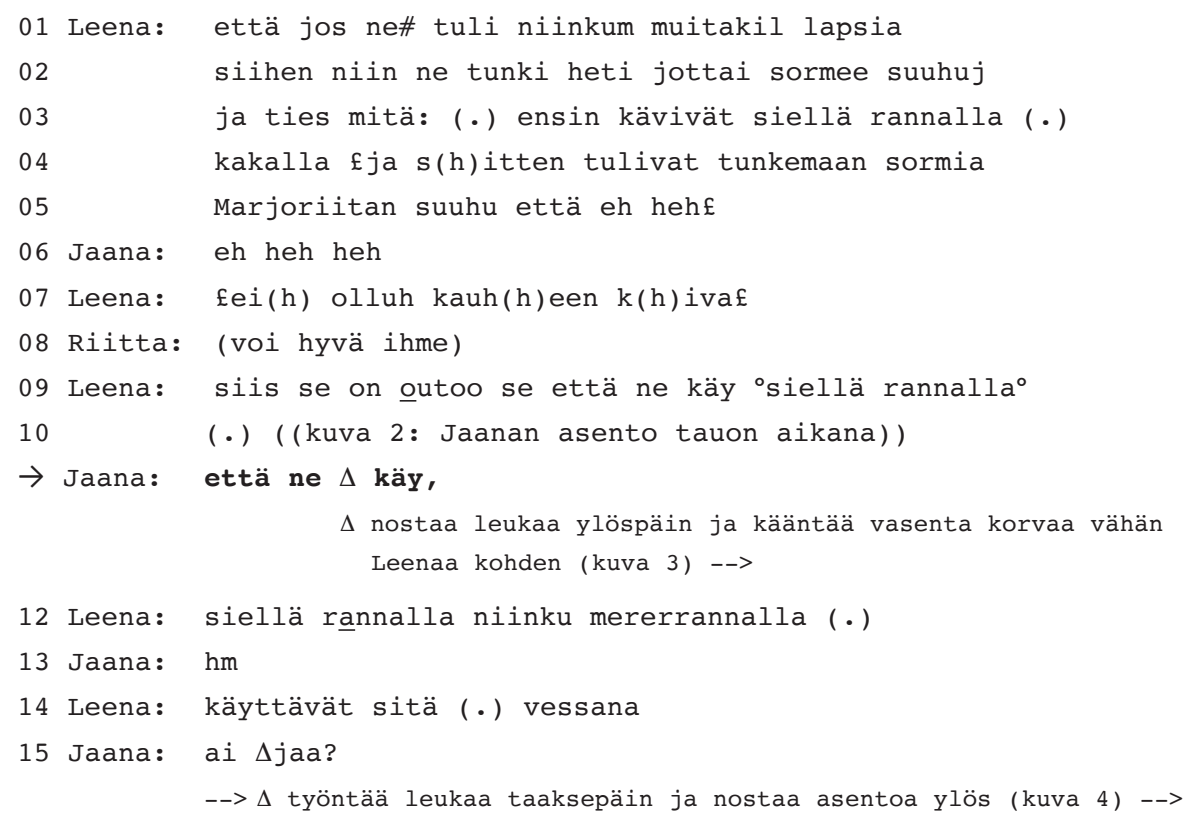




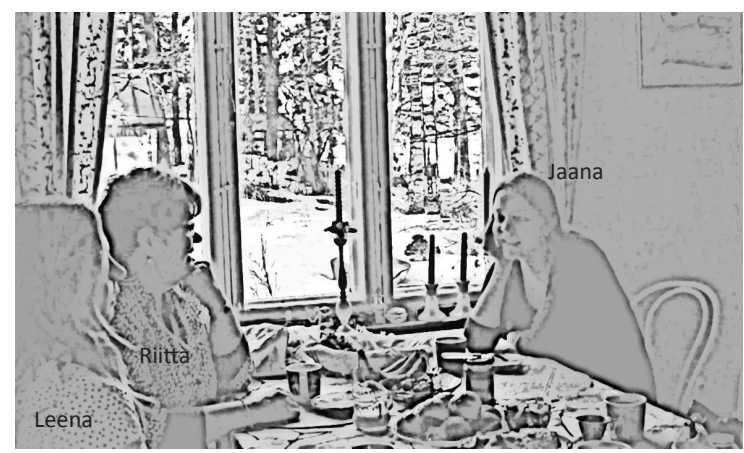

Kuva 2.

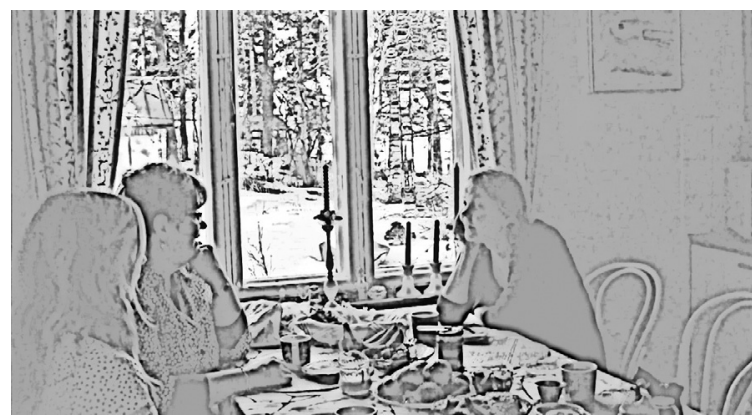

Kuva 3.

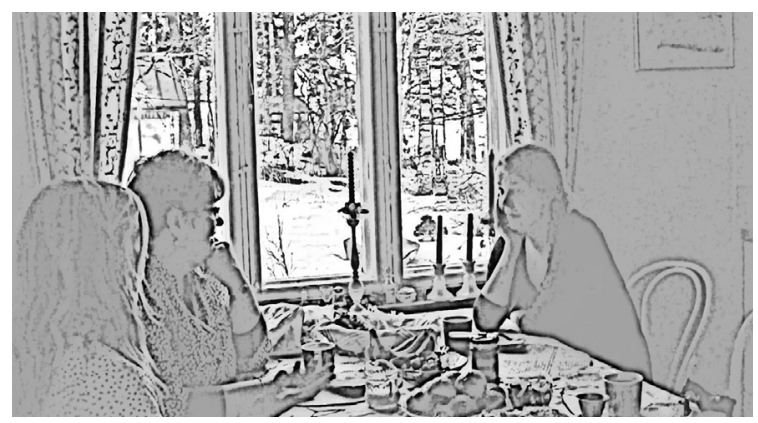

Kuva 4.

Jaana jättää toistamatta vuoron lopusta hiljaisella äänellä lausutun paikan adverbiaalin siellä rannalla (r. 11). Hänen toistonsa on sävelkulultaan tasainen ja kuulostaa selvästi keskenjätetyltä. Merkityksellistä on myös toistoon liittyvä kehollinen toiminta: Jaana työntää ylävartaloaan kohti pöydän toisella puolella istuvaa Leenaa ja kääntää toista korvaansa hieman tämän suuntaan. Tämä kehollinen toiminta vihjaa, että hänen toistonsa liittyy nimenomaan kuulemisongelmaan (ks. myös Mortenssen 2016). Jaana pysyy samassa asennossa siihen saakka, että Leena on saanut selityksensä loppuun: Leena toistaa ensin ongelmavuorossa olleen paikan adverbiaalin ja sitten vielä täsmentää, että kyse oli nimenomaan merenrannasta (r. 12). Hän siis käsittelee Jaanan toistoa ensisijaisesti osoituksena kuulemisen ongelmasta. Jaana ottaa tämän jälkeen uutisen 
vastaan ai jaa -partikkeliketjulla ja asentoa vaihtamalla (ks. kuvaa 4; asennon "jähmettymisestä” korjausjakson ajaksi ks. Floyd, Manrique, Rossi \& Torreira 2014).

Esimerkissä 3 Jaanan toistossa on monia piirteitä, jotka osoittavat, että se on tunnistettavasti kesken ja hakee täydennystä. Ensinnäkin toiston tasainen prosodia implikoi keskeneräisyyttä. Toiseksi Jaana toistaa siinä ongelmavuorosta käydä-verbin, joka inhimillistarkoitteiseen subjektiin liittyessään on kaksipaikkainen ja vaatii seurakseen subjektin lisäksi joko tavan tai paikan adverbiaalin. Kun tätä adverbiaalia ei ole pantu ilmi, lausuma jää tunnistettavasti keskeneräiseksi. Myös Rossi (2015: 275) on samankaltaisia toistoja italiankielisistä keskusteluista analysoidessaan todennut, että kyseiset toistot voivat olla syntaktisesti tunnistettavasti kesken.

Kuulemisen ongelmiin liittyvät toistokorjausaloitteet ovat aineistossamme yhtä lukuun ottamatta peräisin monenkeskisistä keskustelutilanteista. Niissä kuuleminen saattaa ajoittain olla haasteellisempaa kuin kahdenkeskisissä keskustelutilanteissa. Toisaalta edellä esitetyt esimerkit eivät erityisesti tue tällaista oletusta, sillä niissä kummassakaan ei esimerkiksi ole runsaasti päällekkäispuhuntaa. Monenkeskisten keskustelujen osallistumiskehikko (ks. Seppänen 1997) on kuitenkin erilainen kuin kahdenkeskisten, ja on mahdollista, että monenkeskisissä tilanteissa on enemmän vaihtelua siinä, millä intensiteetillä osallistujat ovat mukana.

\subsection{Toisto osoittamassa selityksen tarvetta}

Toisen toistokorjausaloitteiden ryhmän muodostavat tapaukset, joissa ongelmavuorosta toistetaan yksittäinen sana ja joissa toistettua sanaa ryhdytään selittämään seuraavassa vuorossa. Kuten edellä todettiin, nämä toistot ovat hyvin samankaltaisia kuin väärinkuulemisiksi paljastuvat toistot. Ryhmien välinen ero paljastuu vasta, kun tarkastellaan sitä, miten toistoja käsitellään.

Esimerkissä 4 Samin toisto (r. 5) nostaa Vesan edeltävästä vuorosta esiin papusanan, joka on ongelmavuorossa papusäkki-yhdyssanan määriteosana.

(4) Papu

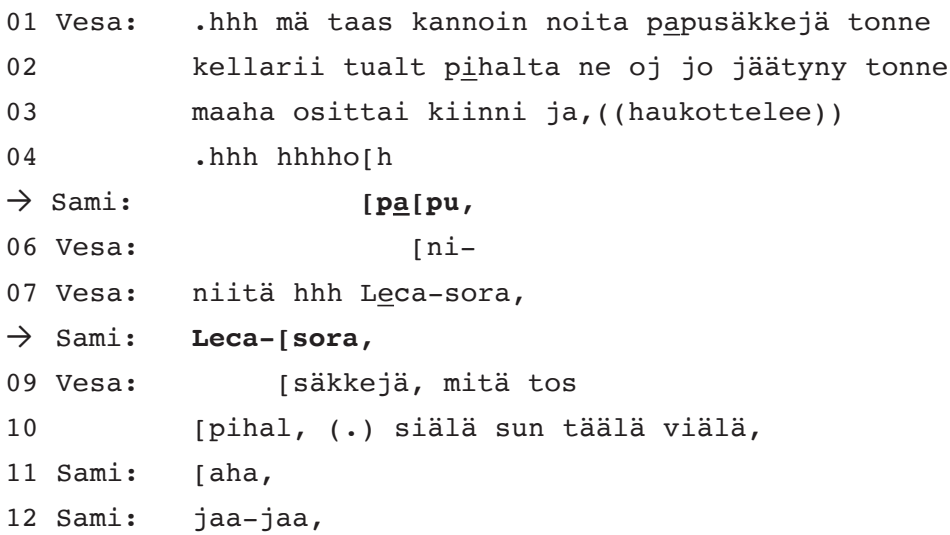


Samin papu-toisto (r. 5) on prosodisesti neutraali ja sävelkulultaan varsin tasainen, kuten kuvio 2 näyttää. Kuulohavaintojemme perusteella se on prosodialtaan samankaltainen kuin ensimmäiseen ryhmään liittyvät väärinkuulemistoistot: prosodian perusteella ei siis ole selvästi pääteltävissä, onko toisto osoitus kuulemisen vai ymmärtämisen ongelmasta.

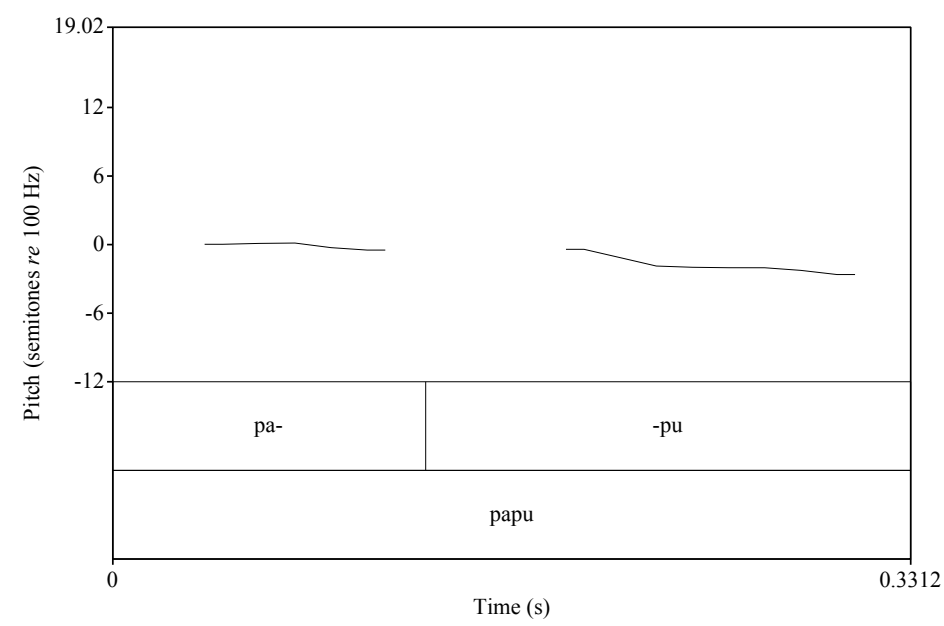

Kuvio 2.

papu-toiston sävelkulku.

Toistoa seuraava selitys alkaa esimerkissä 4 siten, että Vesa tarjoaa toistetulle ilmaukselle täsmällisemmän nimityksen Leca-sora (r. 7). Kun Sami kuitenkin toistaa myös tämän (r. 8), selitys jatkuu puheena olevan sanan tarkoitteen väljemmällä kuvauksella (r. 9-10). Korjausvuorot siis suuntautuvat toistoihin osoituksena siitä, että Sami ei oivalla, mihin toistetut sanat ( $p a p u$, Leca-sora) viittaavat. On tärkeä huomata, että kyse ei tässä siis ole toistetun sanan merkityksen tuntemisesta vaan tarkemmin sen oivaltamisesta, mikä on sanan tarkoite juuri tässä kontekstissa. Samantyyppiseen ongelmaan liittyy esimerkki 5, jossa Repe kertoo Pasille autostaan, joka vuotaa öljyä (r. 1-2). Esimerkin jatko osoittaa, että Repe käsittelee käyttämäänsä vuotaa-verbiä epätäsmällisenä ja suuntautuu Pasin toistoon (r. 3) osoituksena siitä, että Pasilla on vaikeuksia hahmottaa, mihin sana liittyy.

(5) Konevika

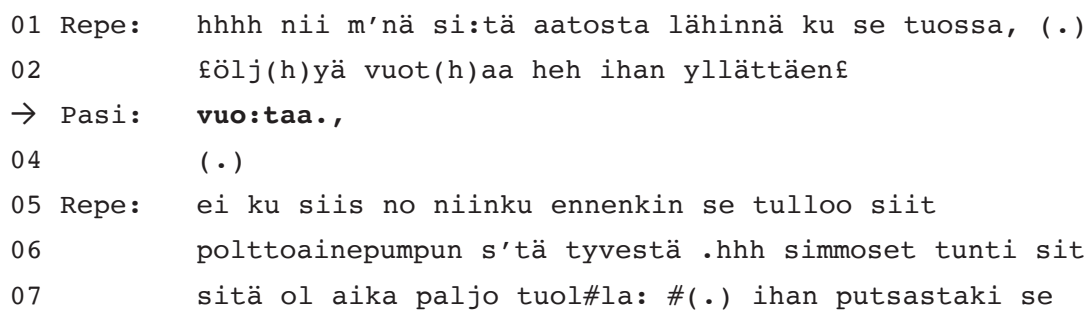




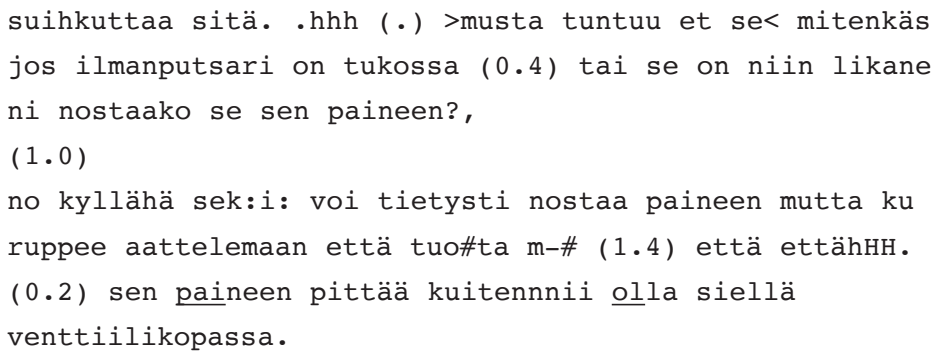

Repe aloittaa toistoa seuraavan vuoron (r. 5-10) korjauspartikkelilla eiku (ks. Haakana \& Visapää 2014) ja vaihtaa tämän jälkeisessä selityksessään Pasin käyttämän vuotaa-verbin yleisverbiksi tulla (r. 5). Hän kuvailee tarkemmin, mistä öljyä tulee ja sitten vielä täsmentää tulemisen tapaa: "se" jopa suihkuttaa öljyä (r. 7-8). Selitys siis käsittelee vuotaa-toistoa osoituksena siitä, että tähän sanavalintaan liittyy jotakin ongelmallista: se ei ole kontekstissaan ymmärrettävä tai on sikäli ongelmallinen, että se ei kuvaile öljyn valumisen tapaa täsmällisesti, ja siksi sitä on selitettävä.

Kaiken kaikkiaan tämänkaltaiset toistot, joita käsitellään osoituksina jonkinlaisesta selityksen tarpeesta, ovat aineistossamme harvinaisia. Tämä on sikäli kiinnostavaa, että esimerkiksi kakkoskielisessä keskustelussa toisen kielen puhujat käyttävät toistoja nimenomaan osoittamaan, että toistetun sanan merkitys on vieras ja kaipaa tarkentamista (Lilja 2014). On toki todennäköisempää, että keskustelussa esiintyy tuntemattomia sanoja, jos puhuja on vasta ottamassa haltuun keskustelussa käytettävää kieltä, mutta kuten edellä olevat esimerkit osoittavat, selitystä voidaan kaivata myös tietyn, sinänsä tutun sanan ( $p a p u, v u o t a a)$ merkityksestä kontekstissaan. Tällaiset toistot vastaavat suurin piirtein Robinsonin (2013) tutkimia tapauksia, joissa vastaanottaja päättelee toistajan olevan episteemisesti tietävässä $(\mathrm{K}+)$ asemassa toistettavaan elementtiin nähden. Jos vastaanottaja ei tunne sanaa tai ilmausta (K-), ensikieltään puhuvien suomenkielisissä keskusteluissa on tyypillisempää, että tuntemattomiin ilmauksiin reagoidaan kysymyslausemuotoisilla korjausaloitteita eikä niinkään toistoilla (ks. Haakana ym. 2016).

\subsection{Toisto ennakoi erimielisyyttä}

Kolmanteen aineistostamme erottuvaan toistokorjausaloitteiden ryhmään kuuluvat tapaukset, joissa toistoa seuraa pelkkä vahvistus, jonka jälkeen toistaja esittää jonkinlaisen korjauksen tai varauksen suhteessa ongelmavuoroon. Näissä tapauksissa ei ole kyse yhtä selvästi kuulemisen tai ymmärtämisen ongelmista kuin edellä käsitellyissä tapauksissa. Sen sijaan toistot osoittavat muuntyyppistä ongelmaa edeltävän vuoron vastaanottamisessa tai sen implikaatioiden hyväksymisessä. Esimerkit 6 ja 7 havainnollistavat tämän ryhmän tapauksia. Esimerkissä 6 Jari ja Reino keskustelevat sään ennustamisesta. Reino on kertonut tuttavastaan, joka on onnistuneesti ennustanut säää. Tähän reaktioksi Jari kysyy, mitä Aino on ennustanut (r. 1-2). 
(6) Ainolta

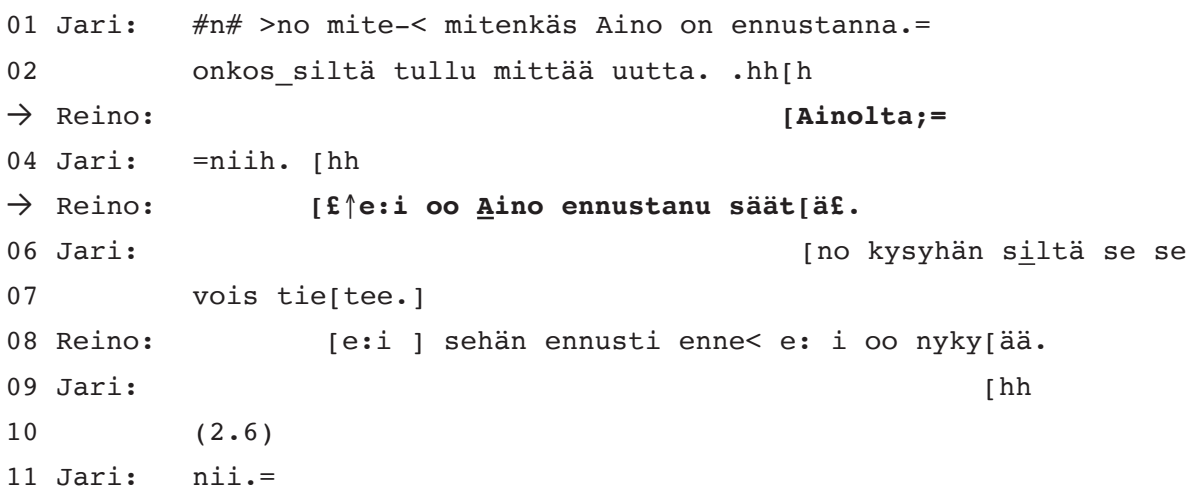

Reino toistaa Aino-nimen (r. 3) ja yhdistää nimeen ablatiivin sijapäätteen, joka kysymysvuorossa esiintyi Ainoon viittaavassa pronominissa. Prosodialtaan toisto on neutraali ja sävelkulultaan lievästi laskeva. Jari vahvistaa toiston niin-partikkelilla (r. 4), minkä jälkeen Reino korjaa kysymyksen olettamuksia: Aino ei hänen mukaansa ylipäätään ennusta enää säätä (r. 5). Tässä siis Ainolta-toisto osoittaa, että Jarin kysymykseen liittyy Reinon näkökulmasta ongelmallinen implikaatio siitä, että Aino ennustaisi säätä. Koska Aino ei ennusta säätä, kysymykseen vastaaminen on mahdotonta.

Esimerkissä 7 toisto on samankaltaisessa käytössä. Esimerkki on kolmen nuoren tytön keskustelusta. Milja on edellä keskustelussa kertonut kirjastoreissustaan, jonka aikana hän on nähnyt keskustelijoiden tuttavan Heidin, joka oli liikkeellä Teron kanssa. Tähän reaktiona Lotta alkaa kertoa, että myös hän on nähnyt Heidin Teron kanssa, mutta alkaa myös pohtia, oliko Heidin kanssa ollut poika sitten lopultakaan Tero. Tätä pohdintaa jatkuu jonkin aikaa, ja kaikki osallistujat esittävät asiasta näkemyksiään.

(7) Kirjakaupassa

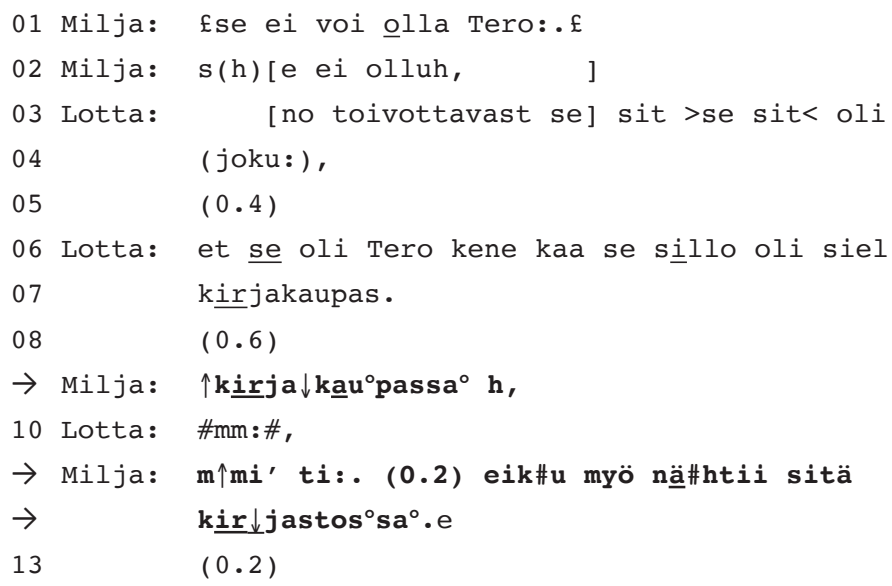




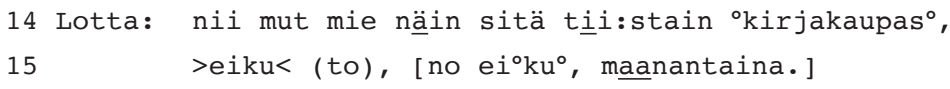

Pohdinta Teron henkilöydestä saavuttaa jonkinlaisen päätöksen Lotan vuoroissa (r. 3-7). Tätä vuoroa seuraa melko pitkä tauko (r. 8), jonka jälkeen Milja toistaa kirjakaupassa-adverbiaalin (r. 9). Prosodialtaan Miljan toisto (r. 9) on hyvin kohosteinen. Se alkaa huomattavan korkealta ja laskee voimakkaasti loppua kohden, kuten kuviosta 3 näkyy. Toistonsisäinen sävelkorkeuden vaihtelu on suuri, ja näin ollen tämä toisto tulee prosodialtaan lähelle sellaisten tapausten prosodiaa, joita esimerkiksi Selting (1996) on käsitellyt hämmennystä osoittavina.

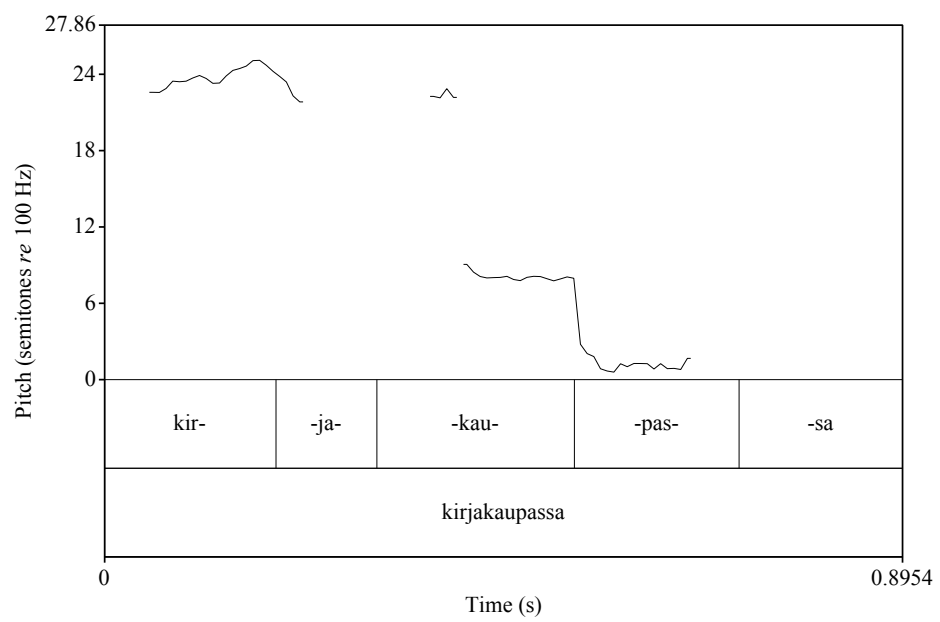

Kuvio 3.

kirjakaupassa-toiston sävelkulku.

Toistoon kiteytyy esimerkissä 7 sekaannus siitä, missä puheena olevat henkilöt on nähty. Miljan kertomus on sijoittunut kirjastoon. Lotta sen sijaan ei vielä aiemmin omassa puheessaan ole ottanut selvää kantaa siihen, missä hän on Heidin ja Teron nähnyt. Ehkä tästä syystä paikan mainitseminen herättää Miljassa hämmästystä, johon hän reagoi ensin toistolla (r. 9) ja sitten korjaamalla, että henkilöt on nähty nimenomaan kirjastossa (r. 11-12).

Esimerkit 6 ja 7 ovat keskenään sikäli erilaisia, että toisto sijoittuu niissä sekventiaalisesti erityyppiseen kontekstiin: Esimerkissä 6 toisto seuraa kysymystä, johon vastaaminen ei onnistu, koska kysymykseen sisältyy vastaanottajan näkökulmasta ongelmallisia implikaatioita. Esimerkissä 7 taas toisto seuraa vuoroa, joka vetää yhteen edeltävän kertomuksen. Toiminnallisesti tämä vuoro rakentuu jonkinlaiseksi toivomukseksi, ja keskustelukumppaneiden olisi odotuksenmukaista tuottaa siihen samanlinjainen reaktio. Koska toivomukseen kuitenkin sisältyy Miljan näkökulmasta virheellinen käsitys paikasta, hän lähtee hakemaan toistolla korjausta asiaan.

Vaikka esimerkeissä 6 ja 7 toistot siis sijoittuvat sekventiaalisesti erityyppisiin asemiin, molemmissa tapauksissa ne osoittavat, että edeltävässä vuorossa on toistajan 
näkökulmasta jotakin virheellistä. Ne tekevät tämän kuitenkin prosodisesti eri tavoin: kirjakaupassa-toiston kohosteinen prosodia osoittaa, että toistetussa sanassa on jotakin ongelmallista tai hämmennystä herättävää. Ainolta-toisto taas on prosodisesti neutraalimpi ja tulee siltä osin lähemmäksi kahden ensimmäisen ryhmän toistoja (ks. esim. 2-5). Erimielisyyttä ennakoivien toistotapausten koostamisessa ensisijainen kriteerimme onkin ollut se, miten toistoa käsitellään: niissä (kuten edeltävissä esimerkeissä 6-7) toistoa seuraa vahvistus, jonka jälkeen toistaja esittää erimielisen näkemyksen tai korjaa sen osan ongelmavuorosta, joka on hänen näkökulmastaan virheellinen. Näissäkin siis toistokorjausaloitteen tehtävä tulee ymmärretyksi vasta retrospektiivisesti. Esimerkiksi Ainolta-esimerkin toisto voisi olla kuulemisen tarkistus (ja sellaisena Jari sitä mahdollisesti käsitteleekin): sen ongelmaa osoittava luonne paljastuu vasta, kun Reino eksplikoi, ettei Aino enää ennusta säätä.

Tässä alaluvussa tarkastelluissa tapauksissa kysymys ei siis ole selvistä kuulemis- tai ymmärrysongelmista siinä mielessä, ettei toistaja olisi kuullut toistamaansa sanaa tai ymmärtäisi sen merkitystä. Sen sijaan toisto osoittaa toistajan suhtautuvan toistettuun seikkaan jonkinlaisella varauksella, olevan erimielinen tai pitävän toistettua seikkaa suorastaan virheellisenä. Tällaiset toistot toimivat korjauksiin yhdistetyn preferenssijäsennyksen mukaisesti: ne nostavat esiin sen elementin, johon ongelmavuoron ongelmallisuus jollain tavalla kilpistyy, ja tarjoavat näin ongelmavuoron puhujalle mahdollisuuden vielä muotoilla omaa puhettaan. Tässä mielessä nämä toistot ovat jossain määrin samankaltaisia kuin tämän artikkelin aluksi esittämämme Schegloffin, Jeffersonin ja Sacksin (1977) korjausartikkelista peräisin oleva esimerkki, jossa toistolla nostetaan esiin virheellinen sana ongelmavuorosta. Aineistomme tapauksissa virheellinen ei kuitenkaan ole yksittäinen sana vaan tuohon sanaan kilpistyvä implikaatio esimerkiksi siitä, että Aino edelleen ennustaisi säätä, vaikka näin ole. Toisin kuin Schegloffin, Jeffersonin ja Sacksin (mas. 368) esimerkissä, näissä tapauksissa toistoa ei kuitenkaan suoraan seuraa ongelmavuoron puhujan korjaus vaan vahvistus. Vahvistuksen jälkeen toistaja esittää seuraavassa vuorossa korjauksen, joka oikaisee ongelmavuorossa olleen ongelman.

Tähän ryhmään kuuluvat toistokorjausaloitteet tulevat lähelle aiemmassa tutkimuksessa käsiteltyjä erimielisyyden ennakointiin tai osoittamiseen käytettyjä korjausaloitteita (ks. esim. Schegloff 2007: 151; Egbert 1997; Sidnell 2006; Wu 2006; Robinson 2013). Näissä tutkimuksissa on todettu, että korjausaloitteet sopivat erimielisyydestä vihjaamiseen tai sen osoittamiseen erityisen hyvin siksi, että ne tarjoavat edeltävän vuoron puhujalle vielä mahdollisuuden muotoilla ongelmavuoroa niin, että vuorosta tulisi sen vastaanottajalle hyväksyttävämpi. Aineistomme tapauksissa tällaisten toistojen vastaanottajat eivät kuitenkaan muotoile ongelmavuoroaan vaan nimenomaan vahvistavat toiston, kuten esimerkeissä 6 ja 7, jolloin toistajan tehtäväksi jää sen osoittaminen, mikä ongelmavuorossa on ongelmallista tai virheellistä.

\subsection{Toisto topikalisoi odotuksenvastaisen tiedon}

Neljäs toistokokoelmamme ryhmä koostuu tapauksista, joissa ongelmavuoron vastaanottaja toistaa sellaisen osan edeltävästä vuorosta, joka ei jollain tavalla ole vastannut hä- 
nen odotuksiaan. Edeltäviin ryhmiin verrattuna nämä tapaukset eivät hahmotu yhtä selviksi korjausaloitteiksi; yleensä puhuja on kuullut toistamansa osan oikein, hän on ymmärtänyt sen merkityksen kontekstissaan eikä hänellä ole siitä eriävää mielipidettä. Kuitenkin ongelmavuorossa on jotakin, jonka toistaja kokee sillä tavoin poikkeukselliseksi tai epäodotuksenmukaiseksi, että hän toistaa kyseessä olevan tiedon, mikä luo tilan toiselle puhujalle vähintäänkin vahvistaa tieto tai mahdollisesti tarjota jokin selitys siinä esiintyvälle odotuksenvastaisuudelle. Se, onko kyseessä korjausjakson aloitus vai uutisarvoisen tiedon vastaanottaminen, ei ole välttämättä aina relevantti eronteko keskustelijoille itsellensäkään, ja tapaukset asettuvat jatkumolle enemmän korjaavista tapauksista vähemmän korjaaviin (ks. myös Thompson, Fox \& Couper-Kuhlen 2015: 60-64).

Vuorojen "korjaavuuden" kannalta yksi olennainen tekijä on niiden sekventiaalinen asema: Jos toisto esimerkiksi keskeyttää meneillään olevan kerronnan, se mieltyy herkemmin korjausaloitteeksi kuin kysymys-vastaus-vierusparia kolmannessa positiossa seuraavaa toisto. Samoin toisto, jota seuraa toistetun sanan selitys, on helpompi hahmottaa korjaukseksi kuin toisto, jota seuraa pelkkä vahvistuspartikkeli. Kuitenkin myös kolmannessa positiossa on mahdollista aloittaa korjaus, ja vastaanottaja voi vahvistaa toiston, jolla puhuja on aloittamassa korjausta.

Kuten edellä on jo käynyt ilmi, sekventiaalisuuden ohella toinen toistojen tulkinnan kannalta merkittävä tekijä on niiden prosodia. Neljännen ryhmän tapauksissa toistojen prosodia kuulostaa kautta linjan jollain tavoin hämmästelevältä. Vaikutelma syntyy siitä, että odotuksenvastaista tietoa topikalisoivat toistot ovat prosodisesti kohosteisia: ne voivat olla korkea-alkuisia tai muuten alkuintensiteetiltään voimakkaampia (ks. Selting 1996). Vaikka näissä toistoissa on kokoelmassamme sama yleislinjaltaan laskeva kuvio kuin ensimmäisen ja toisen ryhmän toistoissa, eroa on kuitenkin korkeuden (tai intensiteetin) vaihteluissa. Tässä ja edellisessä alaluvussa (4.3) käsitellyissä ryhmissä on siis useammin prosodisesti kohosteisia toistoja kuin kahdessa ensin käsitellyssä ryhmässä (ks. lukuja 4.1-4.2).

Seuraavaksi esittelemme kolme odotuksenvastaisiin toistoihin kuuluvaa tapausta, jotka eroavat toisistaan toiston sekventiaalisen aseman ja sen jälkeisen vuoron osalta. Sen sijaan prosodisesti toistot ovat niissä varsin samankaltaisia. Seuraavassa esimerkissä Missu kertoo ystävälleen Kaakalle päässeensä opiskelemaan kotitalousopettajaksi, ja yllättäen hyväksyttyjen listalla on myös ollut hänelle tuttu nimi - vanha lapsuudenystävä Tiina.

(8) Puhelinkeskustelu

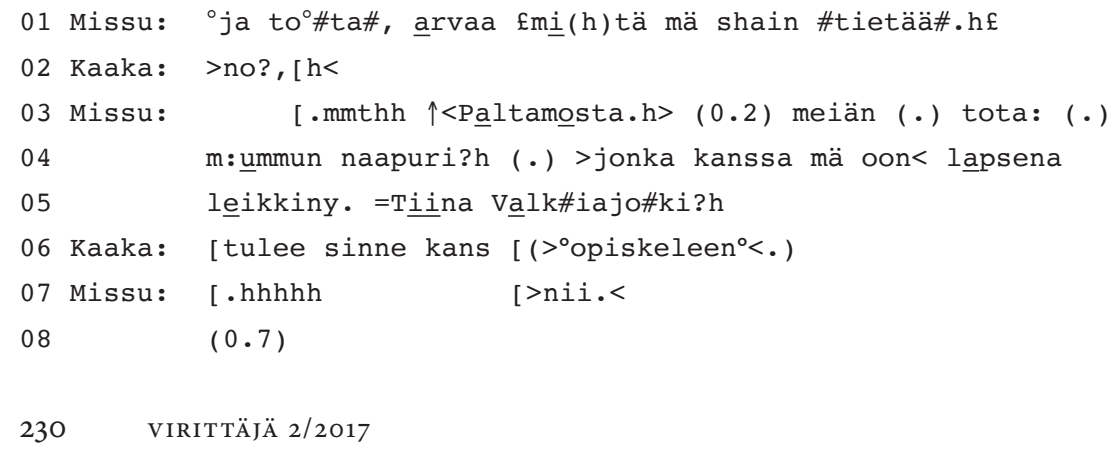




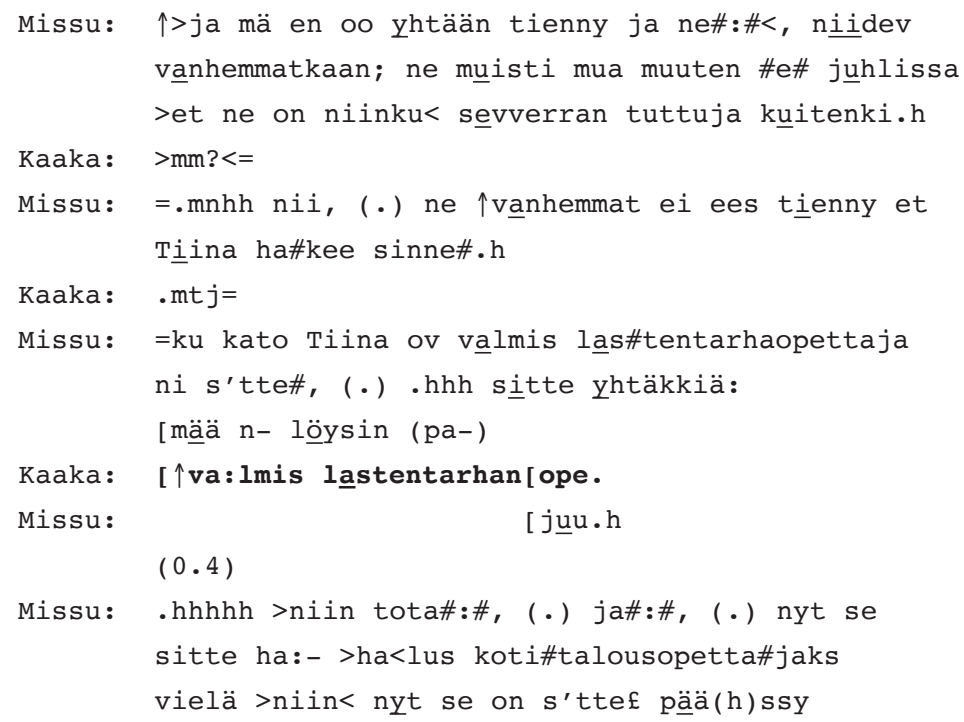

Kesken Missun vanhaa ystävää kuvailevan vuoron Kaaka toistaa osan vuorosta päällekkäispuhunnassa (r. 19). Missu jättää lausumansa kesken (r. 18) ja vahvistaa toiston (r. 20). Tämän jälkeen Missu jatkaa kertomustaan aiheesta (r. 22-24). Katkelman toisto on tulkittavissa korjausaloitteeksi siinä mielessä, että se katkaisee käynnissä olevan toiminnan, joka jatkuu, kun toiston aloittama välisekvenssi on saatu päätökseen. Missu myös käsittelee toistoa selitystä vaativana eksplikoimalla vielä toistettuun elementtiin liittyvää taustatietoa ('vaikka ystävä on valmis lastentarhanopettaja, hän silti halusi opiskella myös kotitalousopettajaksi', r. 22-24).

Toisaalta on huomattava, minkälainen on se Missun toiminta, jonka Kaakan toisto keskeyttää. Missu on kertomassa tarinaa nimenomaan yllättävästä tai odotuksenvastaisesta tapahtumasta. Hän kehystää tarinan uutisen etiäisellä (r. 1 arvaa mitä mä sain tietää) ja tuo tämän jälkeen näyttämölle paikan (r. 3 Paltamosta) ja henkilön (r. 5 Tiina Valkiajoki). Ennen kuin Missu ehtii verbalisoida näiden välistä suhdetta, Kaaka ilmaisee arvaavansa tarinan jatkon esittämällä ymmärrysehdokkaan (r. 6). Missun osaksi jää yllättävän uutisen kertomisen sijaan sen vahvistaminen (r. 7). Missu kuitenkin korostaa tarinan yllätyksellisyyttä fokus- ja kieltohakuisilla partikkeleilla (r. 9 mä en yhtään tienny ja r. 13 vanhemmat ei ees tienny). Kaakan reaktiot (r. 12 ja 15) Missun vuoroihin ovat kuitenkin varsin minimaalisia, ja Missun vuoron niiden jälkeen (r. 16-17) voikin nähdä keinona eksplikoida vielä, mistä tarinan yllättävyys juontuu: hänen ystävällään on jo ammatti, jolloin ei ole odotettavaa, että tämä olisi pyrkinyt vielä opiskelemaan. Tämä tieto kirvoittaakin Kaakalta minimaalisia palautteita vahvemman vuoron, toiston.

Esimerkissä 8 ei siis olekaan aivan selvää, keskeyttääkö Kaakan toisto loppujen lopuksi käynnissä olevaa toimintaa. Vaikka toisto katkaisee Missun käynnissä olevan vuoron (r. 18), voi hänen edeltävät vuoronsa nähdä nimenomaan yrityksenä todistaa tarinan yllätyksellisyyttä (ja siten laajemmin uutisarvoisuutta). Yksi keino ottaa vastaan uutta tietoa on nimenomaan toisto (ks. Thompson, Fox \& Couper-Kuhlen 2015: 84-86). Näin ollen Kaakan toiston voisikin siis nähdä reaktiona siihen yllättävään tietoon, että Missun 
opiskelemaan päässeellä ystävällä on jo olemassa ammatti. Toki Kaaka voisi myös reagoida tietoon esimerkiksi jollakin uutta tietoa vastaanottavalla partikkelilla; toistolla hän nimenomaan nostaa kyseisen asian vielä varmistettavaksi ennen kuin keskustelu jatkuu.

Seuraava esimerkki valaisee tapausta, jossa toisto sijoittuu sekventiaalisesti vielä tunnusmerkittömämpään paikkaan: kolmanteen positioon kysymys-vastaus-vierusparin jälkeen.

(9) Viiskymppiä

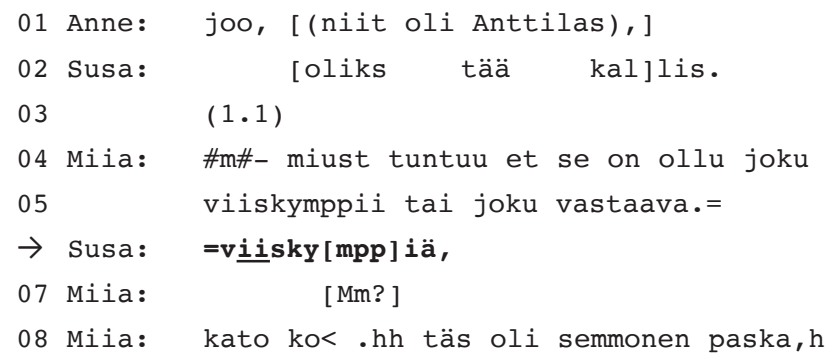

Esimerkissä 9 Anne ja Susa, jotka ovat käymässä Miian luona, ovat ihastelleet sängyn päällä olevaa päiväpeittoa. Susa esittää kysymyksen peiton hinnasta (r. 2), johon Miia vastaa (r. 4-5). Susa reagoi vastaukseen toistamalla sen (r. 6). Sekventiaalisesta asemastaan huolimatta toisto ei ole kuitenkaan pelkkä uuden tiedon rekisteröinti; Susan vastauksen ensimmäinen tavu (viis-) on lausuttu selvästi muuta puhetta suuremmalla intensiteetillä, ja videolta voi havaita hänen ilmeensä viestivän yllättyneisyydestä. Toiston aikana Susa jähmettyy paikalleen katse Miiassa ja artikuloi hinnan korostetun voimakkain suunliikkein. Toiston kohosteinen prosodia ja Susan yliartikulointi osoittavat, että vastauksen sisältämä tieto on ollut jollain tavoin vastoin hänen odotuksiaan. Myös Miia tulkitsee näin, koska kuitattuaan lyhyesti Susan toiston (r. 7) hän alkaa vielä tarkemmin selittää, miksi hinta oli se mikä oli (r. 8).

On huomattava, että edeltävissä esimerkeissä vastaanottajat eivät ainoastaan vahvista toistoja vaan myös alkavat tarkemmin purkaa auki syitä toistettujen ilmausten taustalla. Tämän voi nähdä osoituksena siitä, että toistot eivät toimi ainoastaan uuden tiedon rekisteröintinä vaan että niissä on mukana myös hyväksyttävyyteen liittyvä ulottuvuus. Kuulemisen tai ymmärtämisen ongelmallisuuden sijaan tämän ryhmän toistojen taustalle hahmottuu hyväksymisen ongelma, tietyn tiedon osoittaminen odotuksenvastaiseksi (ks. myös Svennevig 2008; Benjamin \& Walker 2013), johon selityksellä pyritään reagoimaan. Seuraava esimerkki 10 esittää siinä mielessä poikkeavan tapauksen, että puhuja ei oma-aloitteisesti lähde avaamaan toistettua elementtiä vaan ainoastaan vahvistaa toiston.

(10) Oulussa

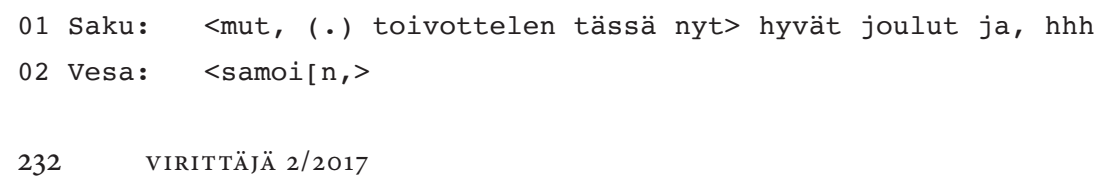




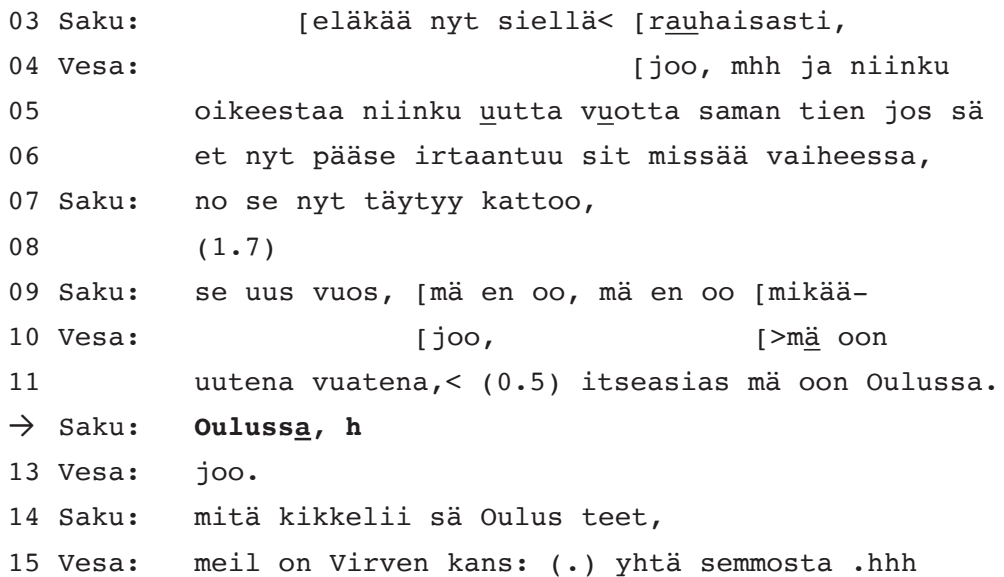

Esimerkin puhelu käydään joulun alla, ja keskustelijat ovat puhuneet, että tapaisivat joulunpyhien jälkeen, mutta tarkempi päivä on jäänyt auki. Vesa vastaa Sakun hyvän joulun toivotuksiin toivottamalla hyvää uutta vuotta (r. 5). Saku tarttuu juhlapyhän ilmaukseen ja lähtee avaamaan siitä keskustelua (r. 7 ja 9). Uusi vuosi ei kuitenkaan ole mahdollinen tapaamispäivä Vesalle, ja niinpä hän kiirehtii päällekkäispuhunnassa kertomaan olevansa muualla uutena vuonna (r. 10-11). Tämän tiedon Saku ottaa vastaan toistolla (r. 12). Toisto on prosodisesti samantyyppinen kuin edellisen esimerkin toisto: ensimmäinen tavu on lausuttu selvästi normaalia suuremmalla intensiteetillä (ks. kuviota 4). Tässä esimerkissä puhuja painottaa myös toiston viimeistä tavua, joskin vähemmän kuin ensimmäistä. Toiston kohosteinen prosodia antaa ymmärtää, että Saku ei ainoastaan rekisteröi Vesan kertomaa tietoa, vaan pitää sitä myös yllättävänä tai odotuksenvastaisena. Kuvio 4 havainnollistaa toiston sävelkulkua.

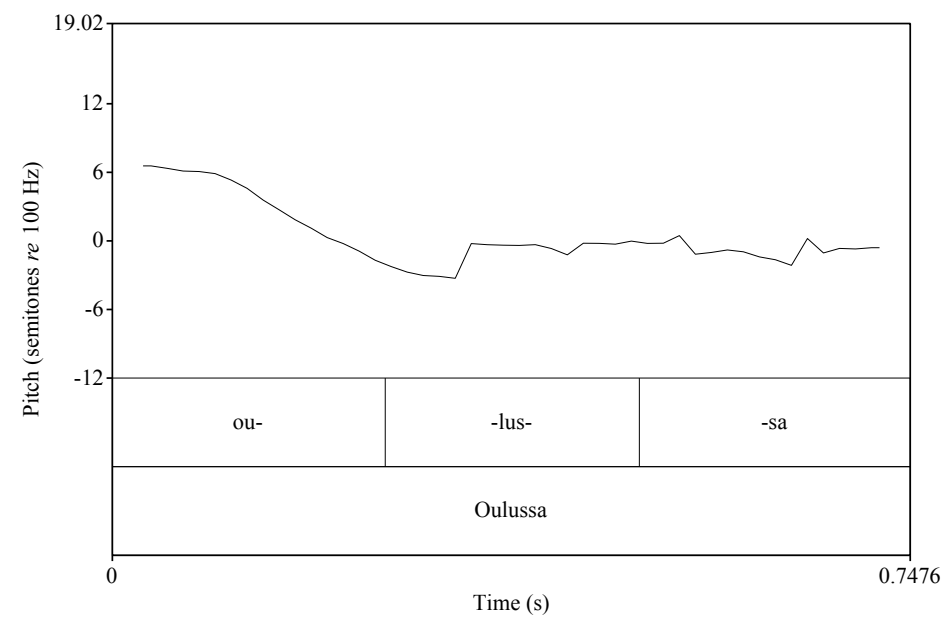

Kuvio 4.

Oulussa-toiston prosodia. 
Vesa reagoi toistoon ainoastaan vahvistamalla sen (r. 13). On kuitenkin ilmeistä, että Sakun toisto osoittaa myös odotuksenvastaisuutta eikä ainoastaan hae vahvistusta; tämä näkyy hänen seuraavasta vuorostaan (r. 14), jossa hän affektisesti muotoillulla (mitä kikkelii) jatkokysymyksellä tivaa syitä Vesan antamaan informaatioon.

Vaikka Vesa ei heti lähdekään avaamaan toistettua lausumaa, hän on kuitenkin tuonut tiedon keskusteluun jollakin tavalla yllättävänä: hän aloittaa tiedon antamisen (mä oon uutena vuatena) mutta pysähtyy hetkeksi ja kehystää lausumansa itse asias(sa) -ilmauksella, ennen kuin tuottaa varsinaisen tiedon paikasta. Uudelleenaloitus ja ilmaus itseasias osoittavat, että paikka ei ole aivan tavanomainen tai odotuksenmukainen. Tämän yllättävän ja yllättävänä esitetyn tiedon Saku sitten ottaa vastaan toistamalla sen. Jälleen voisi siis ajatella, että toisto olisi odotuksenmukainen seuraava reaktio yllättävään tietoon (vrt. esim. 8) pikemminkin kuin keskustelun etenemisen katkaiseva vuoro. Esimerkki 10 kuitenkin osoittaa, että vastaanottajalle ei riitä se, että toisto vahvistetaan; toisto ei siis ole pelkkä uuden tiedon vastaanotto, vaan se samalla myös viestii epäodotuksenmukaisuudesta, joka kaipaa jonkinlaista selvitystä. Tämän ryhmän muissa esimerkeissä 8-9 puhuja avaa oma-aloitteisesti toiston kohteena ollutta lausumaa, mutta kun esimerkissä 10 puhuja tuottaa vain vahvistuksen (r. 13), keskustelukumppani verbalisoi hyväksyttävyyden ongelman penäämällä selitystä epäodotuksenmukaisuudelle.

Uutta tietoa topikalisoivat toistot ovat siis aineistossamme ryhmä, joka sijoittuu korjauksen ja muiden toimintojen rajalle. Ne ovat sekventiaalisesti rajoitetumpia kuin esimerkiksi kuulemisen ongelmiin liittyvät toistot: minkä tahansa elementin edeltävässä puheesta voi kuulla väärin tai olla kuulematta sitä, kun taas odotuksenvastaisen tiedon topikalisointi edellyttää, että aiemmassa vuorossa on esitetty jokin uusi tieto. Kovin tiukka ei sekventiaalinen rajaus sinällään ole; uutta tietoa voi tulla esiin niin vastauksissa kysymyksiin kuin monenlaisissa muissakin vuoroissa. Uutta tietoa topikalisoivien toistojen osalta sekventiaalinen paikka on kuitenkin sikäli merkityksellinen, että toisto on yksi mahdollinen tapa vastaanottaa uutta tietoa (ks. esim. Thompson, Fox \& Couper-Kuhlen 2015: 84-87). Näin ollen uutta tietoa topikalisoiva toisto ei ole samassa mielessä toimintaa keskeyttävä vuoro kuin muissa asemissa tuotetut toistot.

Sekventiaalisesti uutta tietoa topikalisoivat toistot eivät siis välttämättä erotu selvästi korjausaloitteiksi, koska ne esiintyvät paikassa, jossa relevantti seuraava vuoro saattaisi joka tapauksessa olla toisto. Prosodisesti nämä toistot ovat sikäli yhtenäisiä, että kaikissa tapauksissa toistojen prosodia on hämmästelevän kuuloinen. Vaikutelma syntyy ennen kaikkea siitä, että toistot ovat prosodisesti kohosteisia: ne ovat selvästi korkea-alkuisia tai muuten alkuintensiteetiltään voimakkaita. Kuten esimerkin 10 sävelkulkua havainnollistavasta kuviosta 4 käy ilmi, toistossa on selvä korkeuden muutos. On syytä huomauttaa, että Papu-esimerkin (esim. 4, kuvio 2) ja Oulussa-esimerkin (esim. 10, kuvio 4) puhuja on sama; käyristä näkyy, kuinka puhuja hyödyntää omaa prosodista rekisteriään huomattavasti laajemmin toistaessaan odotuksenvastaisen tiedon verrattuna ymmärtämisen ongelmallisuutta viestivään toistoon.

Kuulonvaraisesti neljännen toistoryhmämme tapaukset siis kuulostavat vahvasti ensitavua painottavilta. Koska painokkuuden vaikutelma voi syntyä useista eri osatekijöistä (korkeampi perustaajuus, suurempi intensiteetti), voi tapauksissa myös yh- 
distyä sekä frekvenssin että intensiteetin muutos; kuulonvaraiset havaintomme toki ovat vain suuntaa-antavia. On kuitenkin kiinnostavaa, että tämän ryhmän toistoissa on tiettyä samankaltaisuutta Benjaminin ja Walkerin (2013) hahmottaman "high rise fall" -intonaatiokuvion kanssa. Omassa aineistossamme tosin toistot ovat väljemmin vain painokkaan kuuloisia, eikä korkeuden vaihteluita ole yhtä helppo erottaa. Tämä saattaa osin johtua tarkkojen akustisten mittausten puutteesta, mutta on myös mahdollista, että englanti ylipäätään hyödyntää äänenkorkeuden vaihteluita merkitysten välittämisessä enemmän kuin suomi. Joka tapauksessa on kiinnostavaa, että odotuksenvastaista tietoa topikalisoivat toistomme ovat prosodisesti samantyyppisiä kuin Benjaminin ja Walkerin (2013) tutkimat toistot, jotka nimenomaisesti viestivät ongelmaa toistetun elementin totuudellisuudessa, sopivuudessa tai hyväksyttävyydessä (mas. 107). Jos haluaa määrittää odotuksenvastaista tietoa topikalisoivat toistot korjausaloitteiksi, silloin ongelma, jota ne pyrkivät ratkaisemaan, on nimenomaan hyväksyttävyyden alueella. Toiston tuottaja on kuullut ja ymmärtänyt edellisen vuoron, mutta jokin vuorossa on ollut vastoin hänen odotuksiaan tai oletuksiaan ja sikäli siis "ei heti hyväksyttävissä”. Tämä vastaa myös Seltingin (1996: 246) havaintoa prosodisesti merkityistä toistoista saksan kielessä: hänen mukaansa niillä osoitetaan ristiriita toistetun elementin ja omien odotusten välillä.

\section{Lopuksi}

Olemme tässä artikkelissa tarkastelleet toistoja korjausaloitteina suomenkielisessä keskusteluaineistossa. Olemme havainneet, että toistoilla pyritään ratkaisemaan erityyppisiä ongelmia, joista osa liittyy vahvemmin kuulemisen tai ymmärtämisen tai niiden molempien ongelmallisuuteen (luvut 4.1-4.2) ja osa taas enemmän lausumien hyväksyttävyyteen tai odotuksenvastaisuuteen (luvut 4.3-4.4). Selvimpiä kuulemisongelmien merkitsimiä ovat osittaista kuulemista viestivät toistot (esim. 3), joissa toistaja toistaa kuulemansa osan, mutta jättää lausuman prosodisesti tunnistettavasti kesken, niin että edellinen puhuja voi sen täydentää. Nämä tapaukset ovat samanlaisia kuin Kendrickin (2015: 173) englanninkielisiä ja Rossin (2015: 274) italiankielisiä korjausaloitteita kartoittavissa tutkimuksissa on havaittu (incomplete repeat, hanging repeat). Toisessa kuulemisongelmiin liittyvässä tyypissä, "väärinkuulemisissa" (esim. 2), ongelmalähde määrittyy vasta takautuvasti, kun toiston jälkeen korjauksena esitetään alkuperäinen ilmaus. Toistaessaan puhuja tuottaa sen ilmauksen, jonka on arvellut kuulevansa, eikä siinä vaiheessa ole vielä selvää, mistä ongelmallisuus juontuu.

Osa toistoista liittyy puolestaan enemmän ymmärtämisen ongelmiin. Puhuja on kuullut ilmauksen oikein, muttei pysty hahmottamaan ilmauksen merkitystä tai relevanssia kyseisessä kontekstissa (esim. 4-5). Robinson, joka on jaotellut korjausaloitetoistoja sen mukaan, mikä on puhujien episteeminen asema toistettavan ilmauksen suhteen, kutsuu tällaisia toistoja puhujan erimielisyyttä ilmaiseviksi: " $[\mathrm{K}+]$ actions index their producers' 'disagreement' (for lack of a better term) with the repeated item" (Robinson 2013: 421). Erimielisyys on tässä hyvin laajasti käsitetty termi; omassa aineistossamme pidämme erimielisyyttä relevantimpana erimielisyyttä ennakoivien 
toistojen kuin selityksen tarvetta osoittavien toistojen osalta. Tapaukset, joissa toistolla osoitetaan selityksen tarvetta (ks. lukua 4.2), eivät niinkään ilmaise erimielisyyttä kuin hämmennystä - toistetun ilmauksen relevanssi tai viittauskohde eivät ole selviä puhujalle. Sen sijaan kolmannen ryhmän kohdalla (ks. lukua 4.3) voidaan puhua erimielisyyden ennakoinnista, koska näissä tapauksissa toistoja seuraa toistajan vuoro, jossa hän haastaa puhujan näkemyksen tai esittää siitä erimielisen ilmauksen. Tällaisessa käytössä toistokorjausaloitteiden voi katsoa toimivan Schegloffin, Jeffersonin \& Sacksin (1977) hahmotteleman preferenssijäsennyksen mukaan: sen sijaan, että suoraan esittäisi erimielisen tai korjaavan vuoron, keskustelukumppani tuottaa korjausaloitteen (toiston), joka mahdollistaa sen, että ongelmavuoron puhuja voi vielä tehdä itsekorjauksen.

Vaikka eri toistokorjausaloitetyyppien ongelmalähteitä voi karkeasti jaotella kuulemisen ja ymmärtämisen ongelmiin, on selvää, että raja näiden välillä on liukuva. Väärinkuulemiset ja sanan selitystä hakevat toistot ovat tuottamishetkellä hyvin samanlaisia. Toistamalla keskustelija nostaa esiin ilmauksen, jonka merkitystä tai viittaussuhdetta hän ei lausumassa hahmota (olio, papu). Nämä toistot vastaavat suurin piirtein sitä, mitä Dingemanse, Blythe ja Dirksmeyer (2014: 34) ovat kuvailleet nimellä trouble-presenting repeats. Heidän mukaansa tällaiset korjausaloitetoistot välittävät tietoa siitä, mitä keskustelija on kuullut, mutta samalla osoittavat tiedon puutetta siitä, miten kuultu pitäisi tulkita (mp.).

Väärinkuulemiset ja sanan selitystä hakevat toistot ovat aineistossamme myös prosodisesti varsin samankaltaisia: nämä toistot ovat yleensä nopeasti lausuttuja ilman suuria intonaatio- tai intensiteettivaihteluita. Prosodialtaan kohosteisia ovat puolestaan tyypillisesti uutta tietoa topikaalistavat toistot (ks. lukua 4.4) ja vaihtelevammin erimielisyyttä ennakoivat toistot (ks. lukua 4.3). Esimerkiksi katkelmassa 7 (erimielisyyttä ennakoiva toisto) toistovuoro ( $\left.\uparrow k \underline{\underline{i}} \mathbf{j} a \downarrow k \underline{a} u^{\circ} p a s s a^{\circ}\right)$ on huomattavan korkeaalkuinen ja siten prosodisesti selvästi ympäristöstään erottuva. Tietyllä tavalla erimielisyyttä ennakoivat toistot tulevatkin lähelle uutta tietoa vastaanottavia toistoja - molemmat noteeraavat jotakin odotuksenvastaista edeltävässä puheessa, johon halutaan selitystä tai muokkausta.

Keskustelun toistot ovat siis korjausaloitteenakin sikäli monimuotoinen luokka, että niillä voidaan korjata erityyppisiä vuorovaikutuksen ongelmia. Kuitenkin eri tapauksia yhdistävänä piirteenä voidaan pitää sitä, että ongelmallisuus, jota toistolla lähdetään purkamaan, liittyy väljästi määritellen hyväksyttävyyteen. Ongelmavuoron hyväksyttävyys tulee selvimmin esiin erimielisyyden ennakoinneissa, joissa puhuja nimenomaisesti toiston jälkeen osoittaa, että on eri mieltä ongelmavuorosta eli ei hyväksy sitä. Myös odotuksenvastaisen tiedon topikalisoinneissa voi nähdä ongelman sijoittuvan hyväksyttävyyden alueelle - toiston syynä on juuri esitetyn tiedon odotuksenvastaisuus tai vaikea hyväksyttävyys. Väljästi tulkiten myös värinkuulemisten ja selityksen tarvetta osoittavien toistojen ongelmanlähteiden voi ajatella pohjaavan jonkinlaiseen hyväksyttävyyden aspektiin: nostamalla esiin sanan olio tai papu puhuja osoittaa, että se ei ole ymmärrettävä ( ja siten hyväksyttävä) kontekstissaan, vaan puhujalta vaaditaan lisää kontekstualisointia, jotta kyseisen sanan voi hyväksyä ja sen merkityksen lauseessa hahmottaa. 
Perinteisesti keskustelun korjaustoiminnan on katsottu liittyvän puhumisen, kuulemisen ja ymmärtämisen ongelmien ratkaisemiseen. Ongelmia, joita korjausaloitteella ratkaistaan, ovat suoraviivaisten kuulemisongelmien lisäksi esimerkiksi epäselvät viittaussuhteet tai viittausten tunnistettavuuteen liittyvät kysymykset (ks. Haakana ym. 2016). Aineistomme perusteella näyttää kuitenkin siltä, että toistot korjausaloitteina liittyvät suomalaisessa keskustelussa tyypillisesti tilanteisiin, joissa on (kuulemisen ja/ tai ymmärtämisen ongelmallisuuden lisäksi tai niihin yhteenkietoutuneena) mukana jonkinlaista hyväksyttävyyden ongelmallisuutta - toistettu elementti ei vaikuta olevan odotuksenmukainen kontekstissaan.

Hyväksyttävyys mahdollisena ongelmanlähteenä on nostettu esiin jo aiemmassakin korjaustutkimuksessa. Svennevig (2008) esittää hyväksyttävyyden piiriin kuuluvina mahdollisina ongelmina muun muassa väitteiden totuudellisuuden, puhujan oikeuden toteuttaa tietty toiminto ja lausumien relevanssin kulloisessakin kontekstissa (mas. 337). Sidnell (2010: 130) ei puhu eksplisiittisesti hyväksyttävyydestä, mutta hänen mukaansa "toiston käyttö korjausaloitteena osoittaa usein vastaanottajan haastavan puhujan lausuman sopivuutta, tarkkuutta tai vakuuttavuutta"'. Myös oman aineistomme toistotapausten voitaisiin määritellä haastavan ongelmavuoron tarkkuutta tai totuudellisuutta, ja näin nähdä niiden kuuluvan laajempaan interpersoonaisten ongelmien kenttään, jonka erilaisten esteiden tasoittamiseen korjauskeinosto tarjoaa välineitä (ks. myös Kitzinger 2013: 255).

Olemme tässä artikkelissa tarkastelleet toistoja korjausaloitteina ja pohtineet toiston monimuotoisuutta keskustelun resurssina. Selvimmin korjausaloitteiksi hahmottuvat kuulemis- ja ymmärtämisongelmista viestivät toistot (ks. lukuja 4.1-4.2). Näissä tapauksissa toistosekvenssi jäsentyy niin, että toistoa seuraa toistetun ilmauksen korjaus, täydennys tai selitys. Jos kyse on väärinkuulemisesta, toiston jälkeen tuotetaan alkuperäinen ilmaus; jos kyse on osittaisesta kuulemisesta, tuotetaan jatko toistetulle ilmaukselle, ja jos kyseessä on ymmärtämisen ongelma, sanan relevanssia tai merkitystä kyseisessä kontekstissa tarkennetaan tai avataan. Sen sijaan lausumien hyväksyttävyydestä tai odotuksenvastaisuudesta kumpuavat toistot (ks. lukuja 4.34.4) jäsentyvät eri tavalla: niitä pääosin seuraa vahvistus dialogipartikkelilla, jota sitten voi seurata selitys tai tarkennus. Erimielisyyttä ennakoivia toistoja voidaan kuitenkin pitää sekventiaalisen asemansa puolesta korjausaloitteina sikäli, että ne katkaisevat keskustelun etenemisen ja nostavat elementin edeltävästä puheesta vahvistettavaksi, ennen kuin keskustelu voi jatkua. Sen sijaan uutta tietoa topikalisoivissa toistoissa toistojen sekventiaalinen asema keskustelun katkaisemisessa ei ole yhtä selvä, koska toisto voi myös olla relevantti seuraava vuoro uuden tiedon esittämisen jälkeen (Thompson, Fox \& Couper-Kuhlen 2015: 84-87). Jako selvemmin korjausaloitteiksi mieltyvien tapausten (ryhmät 1-2) ja vähemmän selvien tapausten välillä heijastuu myös väljästi toistojen prosodiaan: kuulemisen tai ymmärtämisen ongelmallisuutta viestivissä tapauksissa vuorojen prosodia on keskimäärin lakonisempaa (korkeuden vaihtelut ovat vähäisempiä) kuin hyväksyttävyyden ongelmallisuutta ilmentävissä (ks. myös Selting 1996). Olemme kuitenkin tarkastelleet vuorojen proso-

6. Käännös on omamme. 
diaa melko karkeasti, ja jatkotutkimuksen tehtäväksi jääkin selvittää prosodian vaihteluita tarkemmin. Toiston monikäyttöisyys vuorovaikutuksessa kutsuu tutkimaan, miten prosodia auttaa tulkitsemaan moniulotteisen kielellisen resurssin merkitystä. Toinen jatkotutkimuksen selvitettäväksi jäävä alue on toisto osana uuden tiedon vastaanottoa; miten toisto suhteutuu esimerkiksi uutta tietoa vastaanottaviin partikkeleihin (ks. Koivisto 2015a, 2015b)?

\section{Lähteet}

Antaki, Charles 2012: Affiliative and disaffiliative candidate understandings. - Discourse Studies 14 S. 531-547.

Benjamin, Trevor 2012: When problems pass us by. Using "you mean" to help locate the source of trouble. - Research on Language and Social Interaction 45 s. 82-109.

- 2013: Signaling trouble. On the linguistic design of other-initiation of repair in English conversation. Grodil Dissertations in Linguistics 121. Groningen: University of Groningen.

Benjamin, Trevor - Walker, Traci 2013: Managing problems of acceptability with high rise fall repetitions. - Discourse Processes 50 s. 107-138.

Dingemanse, Mark - Blythe, Joe - Dirksmeyer, Tyko 2014: Fortmats for otherinitiation of repair across languages. An exercise in pragmatic typology. - Studies in Language 38 s. 5-43.

Dingemanse, MARK - Enfield, Nick 2015: Other-initiated repair across languages. Towards a typology of conversational structures. - Open Linguistics 1 s. 98-118. DOI:10.2478/ opli-2014-0007.

Drew, PAUl 1997: "Open" class repair initiators in response to sequential sorts of troubles in conversation. - Journal of Pragmatics 28 s. 69-101.

Egbert, Maria 1997: Some interactional achievements of other-initiated repair in multiperson conversation. - Journal of Pragmatics 27 s. 611-634.

Enfield, Nick - Dingemanse, Mark - Baranova, Julija - Blythe, Joe - Brown, Penelope - Dirksmeyer, Tyko - Drew, Paul - Floyd, Simeon - Gipper, Sonja - Gísladóttir, Rósa - Hoymann, Gertie - Kendrick, Kobin H. - Levinson, Stephen C. - Magyari, Lilla - Manrique, Elizabeth - Rossi, GiovanNi - San Roque, Lila - Torreira, Francisco 2013: Huh? What? A first survey in 20 languages. - Makoto Hayashi, Geoffrey Raymond \& Jack Sidnell (toim.), Conversational repair and human understanding s. 343-380. Cambridge: Cambridge University Press.

Floyd, Simeon - Manrique, Elizabeth - Rossi, Giovanni - Torreira, Fransisco 2014: Timing of visual bodily behavior in repair sequences. Evidence from three languages. - Discourse processes. DOI: 10.1080/0163853X.2014.992680.

HaAkana, MarkKu 2011: Mitä ja muut avoimet korjausaloitteet. - Virittäjä 115 s. 36-67.

Haakana, Markku - Kurhila, Salla - Lilja, Niina - Savijärvi, Marjo 2016 : Kuka, mitä, häh? Korjausaloitteet suomalaisessa arkikeskustelussa. - Virittäjä 120 s. 255-293.

HaAkAna, MarkKu - Visapä̈̈, LAUra 2014: Eiku - korjauksen partikkeli? - Virittäjä 118 S. $41-71$.

Hayashi, Makoto - Raymond, Geoffrey - Jack Sidnell (toim.) 2013: Conversational repair and human understanding. Studies in Interactional Sociolinguistics 30. Cambridge: 
Cambridge University Press.

ISK = Hakulinen, Auli - Vilkuna, Maria - Korhonen, Rittta - Koivisto, Vesa - Heinonen, Tarja-Rittta - Alho, Irja 2004: Iso suomen kielioppi. Suomalaisen Kirjallisuuden Seuran Toimituksia 950. Helsinki: Suomalaisen Kirjallisuuden Seura.

Kendrick, Ков In H. 2015: Other-initiated repair in English. - Open Linguistics 1 s. 164-19o.

Kitzinger, Celia 2013: Repair. - Jack Sidnell \& Tanya Stivers (toim.), The handbook of conversation analysis s. 229-256. Hoboken: Wiley-Blackwell Publishing.

KLIPPI, ANU 1996: Conversation as an achievement in aphasics. Studia Fennica Linguistica 6. Helsinki: Suomalaisen Kirjallisuuden Seura.

Koivisto, Aino 2015a: Displaying now-understanding. The Finnish change-of-state token $a a$. - Discourse Processes 52 s. 111-148.

2015b: Dealing with ambiguities in informings. Finnish aijaa as a "neutral" news receipt. Research on Language and Social Interaction 48 s. 365-387.

Koshik, Irene 2005: Alternative questions used in conversational repair. - Discourse Studies 7 s. 193-211.

Kurhila, Salla 2006: Second language interaction. Amsterdam: John Benjamins.

LAA KSO, Minna 1997: Self-initiated repair by fluent aphasic speakers in conversation. Studia Fennica Linguistica 8. Helsinki: Suomalaisen Kirjallisuuden Seura.

Levinson, StePHen 2013: Action formation and ascription. - Tanya Stivers \& Jack Sidnell (toim.), The handbook of conversation analysis s. 103-130. Hoboken: Wiley-Blackwell Publishing.

LilJA, NiIn 2010: Ongelmista oppimiseen. Toisen aloittamat korjausjaksot kakkoskielisessä keskustelussa. Jyväskylä Studies in Humanities 146. Jyväskylä: Jyväskylän yliopisto. http:// urn.fi/URN:ISBN:978-951-39-4116-1.

- 2014: Partial repetitions of repair in second language talk. Re-establishing understanding and doing learning. - Journal of Pragmatics 71 s. 98-116.

MondADA, LORENZA 2016: Conventions for multimodal transcription. https://franz. unibas.ch/fileadmin/franz/user_upload/redaktion/Mondada_conv_multimodality.pdf (21.11.2016).

Mortensen, Kristian 2016: The body as a resource for other-initiation of repair. Cupping the hand behind the ear. - Research on Language and Social Interaction 49 s. 34-57. DOI: 10.1080/o8351813.2016.1126450.

PAjo, KATI 2013: Miten huonokuuloisuuteen suuntautuminen näkyy keskustelun korjausjaksoissa? - Virittäjä 117 s. 372-40o.

PAJO, KATI - KLIPPI, ANU 2013: Hearing impaired recipient's non-vocal action sets are source for collaboration in conversation. - Journal of Pragmatics 55 s. 162-179.

Rasmussen, GitTe 2013: Inclined to better understanding. The coordination of talk and 'leaning forward' in doing repair. - Journal of Pragmatics 65 s. 30-45.

Robinson, JefFREy D. 2013: Epistemics, action formation, and other-initiation of repair. The case of partial questioning repeats. - Makoto Hayashi, Geoffrey Raymond \& Jack Sidnell (toim.), Conversational repair and human understanding. Studies in interactional sociolinguistics 30 s. 261-292. Cambridge: Cambridge University Press.

Robinson, Jeffrey D. - Kevoe-Feldman, Heidi 2010: Using full repeats to initiate repair on others' questions. - Research on Language and Social Interaction 43 S. 232-259.

Rossi, Giovanni 2015: Other-initiated repair in Italian. - Open Linguistics 1 s. 256-282.

Schegloff, Emanuel A. 1997: Practices and actions. Boundary cases of other-initiated repair. - Discourse Processes 23 s. 499-546. 
2007: Sequence organization in interaction. A Primer in conversation analysis. Volume 1. Cambridge: Cambridge University Press.

Schegloff, Emanuel A. - Jefferson, Gail - Sacks, Harvey 1977: The preference for self-correction in the organization of repair in conversation. - Language 53 s. 361-382.

Selting, Margret 1996: Prosody as an activity-type distinctive cue in conversation. The case of so-called astonished questions in repair initiation. - Elisabeth Couper-Kuhlen \& Margret Selting (toim.), Prosody in conversation s. 231-270. Cambridge: Cambridge University Press.

Seo, Mi-Suk - Koshik, Irene 2010: A conversation analytic study of gestures that engender repair in ESL conversational tutoring. - Journal of Pragmatics 42 s. 2219-2339.

Seppënen, Eeva-Leena 1997: Osallistumiskehikko. Liisa Tainio (toim.), Keskustelunanalyysin perusteet s. 156-176. Tampere: Vastapaino.

Sidnell, JACK 2006: Repair. - Jan-Ola Östman \& Jef Verschuren (toim.), Handbook of pragmatics s. 1-38. Amsterdam: John Benjamins.

2010: Conversation analysis. An introduction. Hoboken: Wiley-Blackwell Publishing.

Sorjonen, Marja-Leena 1997: Korjausjäsennys. - Liisa Tainio (toim.), Keskustelunanalyysin perusteet s. 111-137. Tampere: Vastapaino.

SvenneVig, Jan 2008: Trying the easiest solution first in other-initiation of repair. - Journal of Pragmatics 40 s. 333-348.

Thompson, Sandra - Fox, Barbara - Couper-Kuhlen, Elizabeth 2015: Grammar in everyday talk. Cambridge: Cambridge University Press.

Wilkinson, Sue - Kitzinger, Celia 2006: Surprise as an interactional achievement. Reaction tokens in conversation. - Social Psychology Quarterly 69 s. 150-182.

Wu, Ruey-JiUAN Regina 2006: Initiating repair and beyond. The use of two repeat-formatted repair initiations in Mandarin conversation. - Discourse Processes 41 s. 67-109.

\section{Liite 1}

\section{Litterointimerkit}

\section{Sävelkulku}

Prosodisen kokonaisuuden lopussa

$\begin{array}{ll}\text {, } & \text { laskeva intonaatio } \\ \text { ? } & \text { tasainen intonaatio }\end{array}$

Prosodisen kokonaisuuden sisällä tai alussa

$\uparrow \quad$ sana lausuttu ympäristöä korkeammalta

$\downarrow \quad$ sana lausuttu ympäristöä matalammalta

joo painotus tai intonaation nousu muualla kuin sanan lopussa

$\uparrow \uparrow \quad$ korkeammalta puhuttu pidempi jakso

$\downarrow \downarrow \quad$ matalammalta puhuttu pidempi jakso 


\section{Päällekkäisyydet ja tauot}

[ päällekkäispuhunnan alku

] päällekkäispuhunnan loppu

(.) mikrotauko: 0.2 sekuntia tai vähemmän

(o.5) mikrotaukoa pidempi tauko; pituus sekunnin kymmenesosina

$=\quad$ kaksi vuoroa liittyvät toisiinsa tauotta

\section{Puhenopeus ja äänen voimakkuus}

$\begin{array}{ll}>< & \text { nopeutettu jakso } \\ <> & \text { hidastettu jakso } \\ \text { joo: } & \text { äänteenvenytys } \\ \circ \circ & \text { muuta puhetta hiljaisempi jakso } \\ \text { JOO } & \text { äänen voimistaminen }\end{array}$

\section{Hengitys ja nauru}

.hhh sisäänhengitys; yksi h-kirjain vastaa yhtä sekunnin kymmenystä

hhh uloshengitys; yksi h-kirjain vastaa yhtä sekunnin kymmenystä

.joo sana lausuttu sisäänhengittäen

mt maiskaus

ha ha partikkeli partikkelilta litteroitua naurua

jo(h)o sana lausuttu nauraen

$£ £$ tai \$ \$ hymyilevä tai naurava ääni; ei varsinaista naurua

\section{Muita merkkejä}

$$
\begin{array}{ll}
\# \# & \text { nariseva ääni } \\
\text { se- } & \text { (tavuviiva); sana jäänyt kesken } \\
(\text { joo }) & \text { epäselvästi kuultu sana tai jakso } \\
(--) & \text { sana, josta ei ole saatu selvää } \\
(---) & \text { pitempi jakso, josta ei ole saatu selvää }
\end{array}
$$

Kehollinen toiminta on litteroitu Mondadan (2016) kehittämiä konventioita noudattaen ja käytetyt merkit ovat seuraavat:

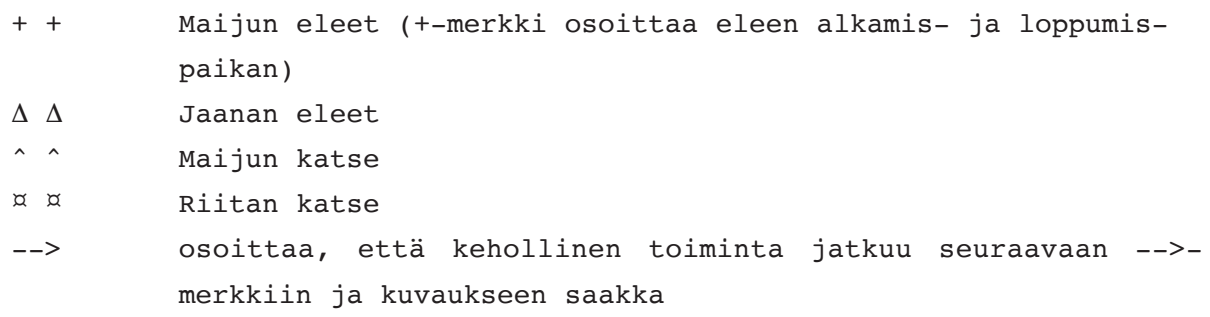




\section{Repetition and the boundaries of repair}

Based in the field of conversation analysis, this study examines certain (partial) repetitions of the prior turn that function as repair initiations. The study aims to determine the types of problems addressed by (partial) repetitions, and to discuss the continuum from repair-initiating repetitions to the closely related phenomenon of acknowledging new information.

The data comprises 37.5 hours of videoed and/or audiotaped everyday conversations in Finnish. Some of the data we have collected ourselves, while some of it is taken from the CA archive at the University of Helsinki. All the conversations examined are informal; the speakers involved are either friends or family members, they are all adults, and they are all native Finnish speakers. The analysis is based on a collection of 46 instances of repair-initiating repetitions extracted from this data.

The analysis shows that (partial) repetition is a multifaceted repair-initiating practice: a repetition can be used not only to indicate the recipient's trouble in hearing or understanding the prior turn, but can also indicate other types of problems. In particular, analysis reveals that repair-initiating repetitions are typical in situations that involve some kind of problem of acceptability, i.e. in which the repeated element is deemed unexpected in the context. Such partial repetitions challenge the accuracy or plausibility of the problematic turn, and hence belong to the larger framework of interpersonal problems. The article discusses the often blurred boundaries between different repair phenomena. 


\section{Toisto ja korjauksen rajat}

Tässä keskustelunanalyyttisessa artikkelissa analysoidaan korjausaloitteena toimivia edeltävän vuoron osittaisia toistoja. Tavoitteena on selvittää, millaisia puheen vastaanottamisen ongelmia edeltävän vuoron (osittaisella) toistolla pyritään ratkaisemaan, sekä pohtia korjausaloitteina toimivien toistojen suhdetta niiden lähi-ilmiöihin, kuten uuden tiedon vastaanottamiseen.

Aineisto koostuu 37,5 tunnista suomenkielisiä ääni- ja videotallennetettuja arkikeskusteluja. Osa aineiston vuorovaikutustilanteista on peräisin Helsingin yliopiston keskusteluntutkimuksen arkistosta ja osa on itse keräämäämme. Kaikki keskustelutilanteet ovat vapaamuotoisia ja epämuodollisia; puhujat ovat ystäviä, sukulaisia tai tuttavia keskenään, kaikki ovat aikuisia ja puhuvat ensikielenään suomea. Analyysi perustuu tästä aineistosta löydettyjen 46 toistokorjausaloitteen kokoelmaan.

Analyysi osoittaa, että toistot ovat hyvin monikäyttöinen korjauksen aloittamistapa. Niillä voidaan osoittaa ongelmia edeltävän puheen kuulemisessa tai ymmärtämisessä. Lisäksi niillä voidaan kuitenkin reagoida muuntyyppisiin ongelmiin. Erityisesti analyysissa nousee esiin havainto siitä, että toistot korjausaloitteina liittyvät tyypillisesti tilanteisiin, joissa on - kuulemis- tai ymmärrysongelmien lisäksi tai niihin yhteenkietoutuneena - myös jonkinlaista hyväksyttävyyden ongelmallisuutta: toistettu elementti ei vaikuta olevan kontekstissaan odotuksenmukainen. Tällaiset toistokorjausaloitteet haastavat ongelmavuoron tarkkuutta tai totuudellisuutta ja kuuluvat näin laajempaan interpersoonaisten ongelmien kenttään. Analyysin pohjalta artikkelissa pohditaan sitä, missä korjausilmiöiden rajat kulkevat.

Kirjoittajien yhteystiedot (addresses):

Salla Kurhila: etunimi.sukunimi@helsinki.fi

Niina Lilja: etunimi.sukunimi@uta.fi 